\title{
SIGNIFICANCE AND DETERMINATION OF FEES FOR MUNICIPAL FINANCE
}

\author{
PETER FRIEDRICH \\ ANITA KALTSCHUETZ \\ CHANG WOON NAM
}

CESIFO WORKING PAPER NO. 1357

CATEgory 1: Public FinANCE

DECEMBER 2004
An electronic version of the paper may be downloaded
- from the SSRN website: www.SSRN.com
- from the CESifo website: www.CESifo.de




\title{
SigNIFICANCE AND DETERMINATION OF FEES FOR MUNICIPAL FINANCE
}

\begin{abstract}
The idea of fiscal decentralisation has become increasingly fashionable world-wide. But every country has unique features of the intergovernmental fiscal system. In general municipal expenditures are rapidly growing in European countries. On the other hand local tax increases are not easily enforceable at present, whereas the local fiscal autonomy is unlikely to be guaranteed as long as municipalities are strongly dependent on down-flow grants. In such a fiscal-stress situation an improvement of local fiscal capacity can be achieved from the increase of fees. Four European countries were chosen to survey the recent development of municipal finance: Britain, Germany, Poland and Switzerland. This paper firstly identifies and highlights the similarities and differences in municipal finance in an international context. Secondly it theoretically examines the possibility of enhancing fiscal autonomy of local governments through determining optimal fee level which leads to an increase of revenues from this revenue item.
\end{abstract}

JEL Code: H2, H4, H6, H7, H8.

Keywords: fiscal decentralisation, local expenditures and taxes, fees, shared taxes, intergovernmental transfers, municipal borrowings, Poland, Britain, Switzerland, Germany.

Peter Friedrich

University of Federal Armed Forces Munich

Werner-Heisenberg-Weg 39

85579 Neubiberg

Germany

peter.friedrich@unibw-muenchen.de
Anita Kaltschuetz

Ifo Institute for Economic Research

at the University of Munich

Poschingerstr. 5

81679 Munich

Germany

kaltschuetz@ifo.de

\author{
Chang Woon Nam \\ Ifo Institute for Economic Research \\ at the University of Munich \\ Poschingerstr. 5 \\ 81679 Munich \\ Germany \\ nam@ifo.de
}




\section{Introduction}

The idea of decentralisation of political decision-making has become increasingly fashionable world-wide, usually accompanied by fiscal decentralisation. Unfortunately municipalities in Europe seem to be presently suffering from a lack of necessary financial means to cover the increasing public activities and expenditures. ${ }^{1}$ The greater sensitivity of sub-central governments to local preferences achieved through the decentralisation "may enhance the ability of the provider to identify both recipients' and citizens' willingness to pay. [P] eople will be more willing to pay for [public] services that they find to be responsive to their priorities, especially if [...] they have been in the decisionmaking process and [...] costs are clearly perceptible in the process. [In other words] decentralisation [would] result in a closer approximation to the efficient solution of provision to the point at which the marginal costs and benefits of provision are equated" (Darby, Mucastelli and Roy, 2003, p. 14) 2

Regarding the efficient provision of local utilities, Oates (1972) emphasises that public expenditures should be assigned in a way that provision of public services is made by the jurisdiction representing the smallest possible area over which the benefits are distributed. Although some inefficiencies could be expected from a multiplicity of tiers of governments (like increased administrative complexity, lack of transparency, clashes in competencies, etc.), the key principle is that the (optimal) size of the sub-central tiers should be selected to well match the broad range of services provided under the consideration of economies of scale. This fact in turn implies that economies of scale from

\footnotetext{
Most common types of public activities legally assigned to local governments include, for example, (a) land planning and local environmental protection, (b) municipal housing and property management, (c) local transport systems, (d) water supply and waste disposal, (e) primary health care and social welfare services, (f) elementary education, (g) culture and sport, fire protection, etc. Yet goods publicly provided have quite often a character of mixed goods, for which some degree of decentralisation combined with some centralised co-ordination appears to be feasible and desirable, due to unclear distribution of benefits among regions, externalities and spill-overs, etc. Furthermore, the central government in many countries can influence the decentralised provision of public goods through the regulation of their delivery in terms of quality and the ex-post control of the use of financial means and transfers.

2 A complete fiscal autonomy can also be disadvantageous. First of all, regional and municipal disparities in income and wealth will lead to different levels of tax revenues in the individual jurisdictions. Secondly, the tax exportation between sub-national jurisdictions can be avoided when taxes are assigned to different levels of government. Thirdly, the mobility of production factors accompanied by tax competition imposes limits on fiscal autonomy. For this reason the most decentralised taxation systems still assign the corporate taxes (on capital) to central government. Finally, fiscal decentralisation can cause administrative complexity in tax collection and provision of public utilities (Blankart and Borck, 2003). The devolution of expenditure responsibilities to local governments can create conflict with the achievement of the macro-economic stabilisation and the re-distributive goal (Oates, 1972). Empirical investigations (including Brosio, 1985) do not always confirm the so-called Leviathan hypothesis by Brennan and Buchanan (1980) that decentralisation generally limits the growth of total government expenditures.
} 
joint consumption of public services set a limit to an ever decreasing size of local governments. According to Tullock (1969), such a problem can be solved by external contracting with large private suppliers or other governments to obtain a service, only if the service is tangible and its quality and standard are safeguarded.

In the provision of infrastructure, local governments tend to (critically) consider an increase in local taxes. ${ }^{3}$ The traditional Tiebout model of revealed preference (1956) postulates "that [citizens] would choose to locate in jurisdictions that provide them with the mix of public services [and the local tax burden] that maximise their welfare. [... Those who] are dissatisfied with the given pattern in their area would [...] move to areas where the pattern [better corresponds their preferences]. So under certain assumptions, diversity of provision [of local utilities and tax burden] combined with consumer mobility can lead to the Pareto-optimal provision [of municipal services]" (Darby, Muscatelli and Roy, 2003, p. 14).

In practice, three main options of assigning funds to local jurisdictions are commonly adopted:

- assignment of (some) taxing power to the central government and financing local expenditure needs by intergovernmental grants or other transfers, for example, in the form of sharing tax revenues,

- assignment of (some) taxing power to the local governments, if necessary complementing the revenues (raised locally) with tax-sharing arrangements with the central government (Norregaard, 1997; Nam and Radulescu, 2003), and

- assignment of rights or requirements to charge fees for financing municipal services.

Intergovernmental transfers are aimed at rectifying not only the vertical imbalance caused by the unequal own tax revenues and expenditures of different levels of governments but also the horizontal imbalance that results from the different fiscal capacities among same level jurisdictions. In the cases of existing externalities on other jurisdictions, the central government also needs to financially support sub-national authorities in order to guarantee the provision of certain public services on the local level like pollution control, inter-regional highways, etc. (Davis and Lucker, 1982; Dahlby, 1996). Furthermore, the amount of grants should vary with the local expenditure needs and inversely with local fiscal capacity, while their distribution must be transparent and fair. More importantly, an effective transfer system should neither encourage overspending nor weaken tax col-

\footnotetext{
There are several characteristics for typical local taxes: (a) Their base should be neither very mobile nor very unevenly distributed among jurisdictions. Otherwise taxpayers will relocate the income activities or tax sources from high to low areas; (b) They should be accountable and local taxpayers should know what the tax liabilities are. In addition, they should be fairly easy to administer on the local level; (c) The link between payment of the tax and local service received should be intact; (d) Local taxes should be able to generate sufficient revenues to avoid large vertical imbalances and ideally be less sensitive to the
} 
lection efforts on the sub-national level (Jones and Cullis, 1994; Shah, 1994a and 1994b; Nam, Parsche and Steinherr, 2001).

Basically the re-allocation of fiscal resources from one level of government to another takes place through the sharing of tax revenues or through a form of grants. In the case of revenue sharing, tax bases can be shared on a tax-by-tax basis, or taxes can be pooled and shared systematically thereafter. According to the previous experiences in emerging countries, such revenue sharing arrangements appear to be less successful in encouraging local revenue mobilisation (Fukasaku and de Mello, 1999). Grants from higher (federal or state) to lower levels (state or local) can be conditional or unconditional respecting the autonomy of local governments in spending such financial means. The block grants also have a fixed character, which are, however, designed to support broad areas of local activities (like education, environmental preservation, etc.) rather than specific projects.

Borrowing has traditionally been an important source to finance long-term public infrastructure projects in advanced countries because it enhances intergenerational equity. In other words, these projects yield returns over several generations, during which the costs for the provision of public goods should be shared equally. This type of intergenerational burden-sharing enables small local governments to undertake the necessary large scale infrastructure investments. However, some countries still impose strict restrictions on local borrowing. For example, in some developing and transition countries large infrastructure projects have recently been more strongly supported in terms of capital grants or lending from higher level governments, since local governments, especially in small entities (due to their weak economic power, small size of tax income and other unfavourable creditworthiness) quite often suffer from the lack of direct access to credit markets. Fiscal deficits and debt have continuously risen over time in a large number of countries both at the state and local levels. The rapid growth of local public debt in a country, which eventually endangers the macro-economic stability, also immediately questions whether the local borrowing is tightly oriented to the necessary financial needs for well-designed local public projects and whether its process is transparent and efficient enough in an administrative sense.

changes in business cycle (Oates, 1972; King, 1984). In accordance with such criteria land or property taxes and, to some extent, personal income taxes have quite often been suggested as suitable local taxes.

4 In general there are four basic debt-control categories: (a) primary reliance on market discipline without the bail-out guarantee of the central government when the credit market is free and transparent information prevails, (b) a dialogue-oriented co-operation and negotiation among different levels of governments in the design and implementation of debt controls (including limits on the indebtedness of sub-national governments), (c) rules-based controls as specified in the constitution or by law regarding, for example, setting purpose- or project-oriented limits on the absolute level of local debts, and (d) direct administrative controls of the central government over local borrowing, including setting of annual limits on the overall debt of individual sub-national jurisdictions, the tight review and authorisation of individual borrowing operations like credit approvals (or the centralisation of all government borrowing) and ex-post monitoring, etc. (Ter-Minassian and Craig, 1997). In Britain basic 
Apart from taxation, public debts and intergovernmental fiscal resource allocations, other modes of finance are relevant for the fiscal autonomy of local governments. They comprise revenues from fees, public enterprise activities, public-private partnership, privatisation, shifting of bureaucratic burdens to other public or private bodies, collecting tributes, revenues from sanctions, concession payments 5 etc. In previous years the issues on fees levied by local governments have not been adequately investigated by public finance experts.

In many countries municipal fees have recently been considerably increased, which has led to an expansion of local revenues from this item. "[C]oncerns over the distortionary effects of tax financing, fairness and a wish to make costs more perceptible to consumers are all factors that potentially support increases in the scope of user charges. [In particular, the OECD] has been critical of low reliance on user charges by various [member] countries in the areas of child care, care of elderly and pharmaceuticals. Trends in these areas suggest that the take-up of free services is booming and that supply-side rationing is considerable. The provision of services free of charge, or without making costs perceptible, obviously risks prompting excessive demand and hitting supply constraints, because the social costs of supply are largely irrelevant for the individual. User charges offer the potential of gaining more information about price sensitivity of demand for services and can potentially render demand pressure directly influential rather than being expressed indirectly and imperfectly through the electoral system. Demand pressures may also be influential on supply-side efficiency. However user charging will be viable only if the costs of collection and of compensation through the benefit system are low relative to the sums that can be levied and the efficiency gains that result. Countries that have tried to increase reliance on fees and charges have generally aimed at striking a balance between copayment and maximum contribution to avoid imposing unduly high expenses on some households" (Darby, Muscatelli and Roy, 2003, p. 29).

As long as profits of public enterprises are yielded from fees, the fiscal autonomy of a municipality is widened. Yet, higher fee revenues that stem from higher sales of public goods by the given fee level require a large-scale production. In countries like Germany there are laws that strictly stipulate the cost coverage of local public firms but do

approvals for loans for individual municipalities are made on the basis of their general need to spend on capital and their usable capital receipts. Specific credit approvals are issued in response to a specific requirement and purpose. Local governments in Britain are not allowed to take credit for financing current expenditures. In Poland total local and regional government debt and loan repayment (principal and interest) must not exceed $60 \%$ and $15 \%$ of the authority's annual income respectively (Council of Europe, 2000).

5 Such concessions include rights to provide energy, to organise passenger traffic, to use the municipal territory for storage, to organise markets, to use urban land for manufacturing, housing, gas lines, electricity and communication infrastructure (Friedrich, Gwiazda and Nam, 2003). 
not allow profit-making (Wienbracke, 2004). As shortly mentioned before, fees allow to close the interest or preference gap between the group of people demanding a public good and those who have to finance its provision. Consequently, charges signal a more clear responsibility for public goods production. Due to this reason fees can also better enable to internalise spill-overs when providing public goods (Rehm, 2004). If there are special expenditure needs of certain citizen groups, the provision of such goods and services does not necessarily reflect the entire public interests. In this case the provision appears to be better financed by fees. In this context fees act as a barrier against socialising local utilities as well. In some cases local investment projects appear to only be financed through charges since other financial means are not available. Credits for financing local projects can also be more easily available, if they are self-financed through the collection of fees. The fiscal consequences of expectation and claim for municipal services can be shown more convincingly, if charges are clearly identified. The information obtained through cost assessment to calculate fees also contributes to other purposes of municipal management and finance. Quite often the increase in fees is not taken into account the improvement of local fiscal capacity indicator when calculating the extent of down-flow transfers. As a consequence grants tend to remain unaffected, although the local receipts from user charges increase. Fees are important when forming a publicprivate partnership, because there is the need to cover cost or allow payment of interests on common equity capital. Otherwise the private partner would not willing to join the partnership.

In general municipal expenditures are rapidly growing in European countries. On the other hand, local tax increases are not easily enforceable at present, whereas the local fiscal autonomy is unlikely to be guaranteed as long as municipalities are strongly dependent on down-flow grants. In such a fiscal-stress situation an improvement of local fiscal capacity can be achieved from the increase of fees. Four European countries were chosen to survey the recent development of municipal finance: Britain, Germany, Poland and Switzerland. This paper firstly identifies and highlights the similarities and differences in municipal finance in an international context. By doing so the significance of fees as municipal revenue source is examined. Secondly it theoretically examines the possibility of enhancing fiscal autonomy of local governments through determining optimal fee level which leads to an increase of revenues from this revenue item. 


\section{Empirical Relevance of Fees for Municipal Finance in the Se- lected European Countries ${ }^{6}$}

Four European countries were chosen to survey the recent development of local finance: Britain, Germany, Poland and Switzerland. By doing so the significance of fees as municipal revenue source is examined. The former three countries are EU members; Germany is also in the euro zone. Regarding the national constitution Britain is centrally structured, while Switzerland and Germany are federal states. Poland also guarantees a substantial degree of municipal autonomy but which is limited compared to that of Germany and Switzerland. Moreover, Poland and the eastern part of Germany are transition economies. Among the selected EU nations and candidates, Germany is the only country currently suffering from the difficulties of satisfying the Maastricht convergence criteria. Switzerland would probably be at the Maastricht limits if it were a member. Britain and Poland presently are among those European countries with an aboveaverage GDP growth rate, whereas Switzerland and Germany have recently experienced rather moderate or low growth. Furthermore the number of native inhabitants of European origin is gradually shrinking in Germany and Britain, whereas the corresponding share of the Swiss population has remained rather stable. At present this is not an important issue in Poland. Due to these different economic, fiscal and institutional characteristics of the investigated countries, one could a priori expect that the local finance system and its development would differ from one country to another.

Overall one can find an increase in total municipal expenditures in the 1990s for all four investigated countries: Germany, Poland, Switzerland and Britain. In Germany total expenditures grew about $23 \%$ from approximately $€ 134$ billion in 1991 to $€ 165$ billion in 2000 with a strong increase until the mid-1990s. Afterwards they slightly declined and started to rise again after 1997 . This development can mainly be attributed to the transformation process of the former GDR, which required investments in different sectors. Municipal expenditures in Switzerland gradually increased from $€ 18$ billion in 1990 to $€ 27$ billion in 2000; that is equivalent to an increase of $47 \%$. Only in 1997 there was a slight reduction. Compared to Germany and Switzerland total expenditures increased even stronger in Britain, namely about 82\% from $€ 88$ billion in 1990/91 to $€ 160$ billion in 2001/02. The development of municipal expenditures is remarkable in Poland: They amounted to $€ 3.4$ billion in 1992 but reached $€ 9.8$ billion ten years later. In part

\footnotetext{
6 All figures concerning municipal expenditures and revenues for Germany can be found in Statistische Bundesamt (2003a), p. 12 and Statistisches Bundesamt (2003b), p. 517, for Switzerland in Bundesamt für Statistik (2003), p. 806 and p. 800, for Britain at the UK Office of the Deputy Prime Minister (2003 and former years) and for Poland in Polish Official Statistics, Regional Data Bank, http://www.stat.gov.pl. For Britain we examine the development of municipal revenues and expenditures in England representatively, since data for the entire territory are not available.
} 
this three-fold expansion reflects the impact of the transformation process: Polish gminas (communes) were underdeveloped and investments were necessary to build up (public) infrastructure of all kinds.

More immediately the development of local expenditures was triggered by the strong increase of social welfare/health care and education expenses which are at the same time one of the largest expenditure categories in the investigated countries (see Figure 1).

Figure 1: Largest Categories of Expenditures

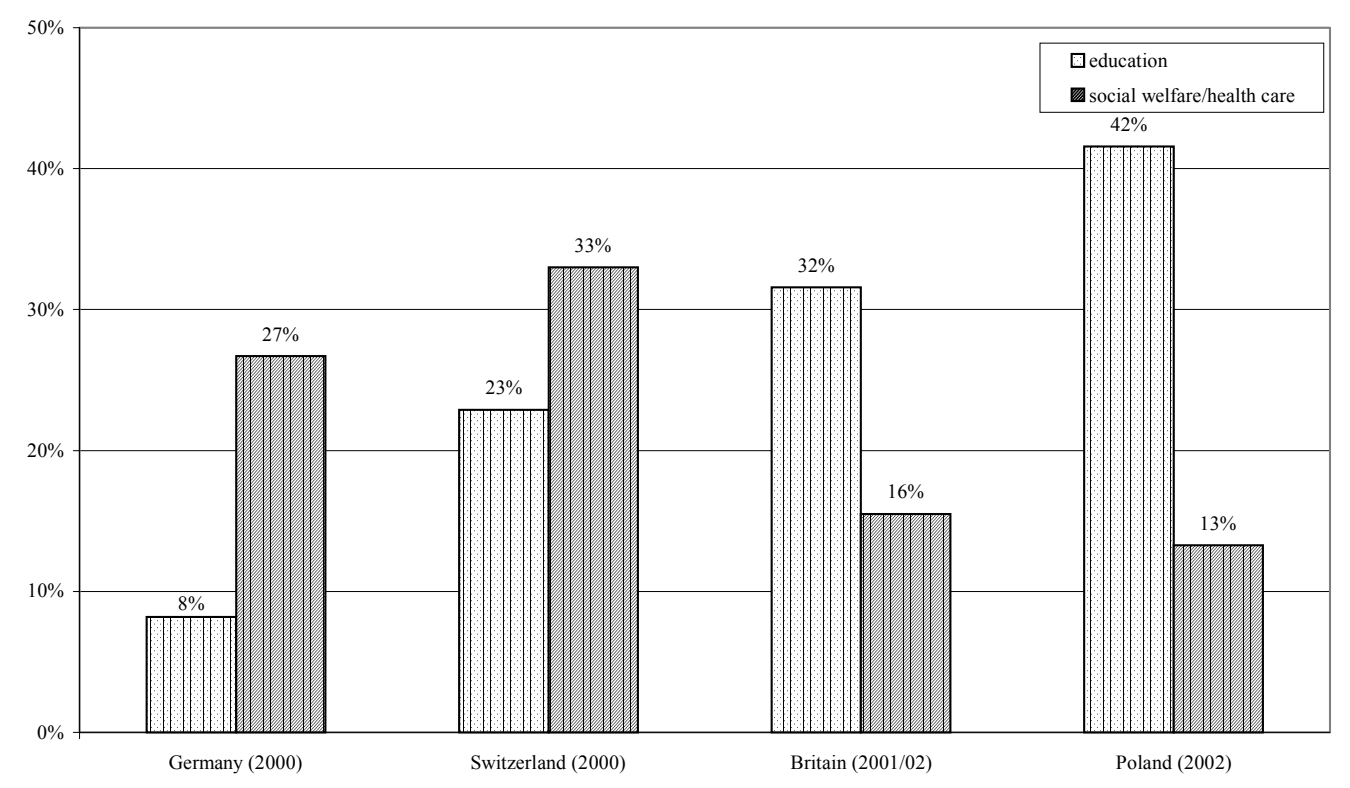

Source: Ifo Institute

In fact there was an increase of expenditures for schooling of about $9 \%$ in Germany in the 1990s but this share still amounts to less then 10\% in 2000. Expenditures for education increased nearly 52\% in Switzerland and $67 \%$ in Britain in the same time period. This strong increase in both countries does not reflect an underdeveloped education system as it existed in Poland after the socialistic era, but shows that Switzerland and Britain attach importance to the improvement of schooling and education. This is also likely to happen in Germany.

7 Important municipal expenditures are also staff expenses (with a share of $9 \%$ in Germany, $8 \%$ in Switzerland and nearly 14\% in Poland), expenses for construction, housing and traffic (with a share of $12 \%$ in Germany and 7\% in Switzerland), telecommunication (in Poland the share of these expenditures increased from $2 \%$ to $11 \%$ in ten years), public facilities and business promotion (with a share of $10 \%$ in Germany), general finance and communal economy. 
Expenditures for social aid increased about $46 \%$ in Germany until 1995. New federal laws, which directed insurance agencies to take care of the elderly people, placed limits on social aid and reduced nursing fees, leading to a decrease in social welfare expenditures in the following years. But after 1999 they rose again so that one can notice an increase of these expenditures of 33\% for the whole 1990s and they reached a share of about $27 \%$ of total municipal expenditures in 2000 . In the same period expenditures for social welfare increased by about $96 \%$ in Switzerland, but they only comprise a share of $15 \%$ of total municipal expenditures. But together with expenditures for health care, which increased from $€ 3$ billion to nearly $€ 5$ billion in 2000 , the share amounted to $33 \%$. Although one can notice an increase of $206 \%$ of these expenditures in Britain in the studied period, the share of social welfare is with $16 \%$ by far not as high as in Germany and Switzerland. Concerning expenditures for health care and social welfare in Poland, one can observe an increase in their share until 1995. Thereafter this share declined to $13 \%$ of total municipal expenditures in 2002 . Thus a change in the social system took place during the transformation process, although its scale is not as large as the one in Germany. Regarding the forthcoming problems in this sector, this can be a comparative advantage of the country.

To prevent a continued increase of the expenditures for social welfare followed by demographic changes, reforms have to take place as soon as possible. Otherwise the share of social aid expenses to total municipal expenditures will continue to grow, not only in Germany and Switzerland, countries with a mature social system, but also British and Polish municipalities will need more financial resources - like fees - to cover these expenses.

Local revenues correspondingly grew in all four countries over the investigated period: In Germany the amount increased from about $€ 100$ billion in 1991 to $€ 145$ billion in 1995, which reflects the unification boom in the municipalities of the former GDR. After a drop to $€ 141$ billion in 1997 due to a reduction of current grants, local revenues reached $€ 148$ billion in 2000 . Tax revenues increased - except for slight business cycle fluctuations - until 2000, because of the participation of (western German) municipalities in income taxation and the local business tax, i.e. a tax on profit. Moreover, German municipalities have increased property and business tax rates. In Switzerland municipal revenues also gradually increased from $€ 18$ billion in 1990 to $€ 29$ billion in 2000 . Furthermore, tax revenues, which represent the main source of revenues, continued to rise with exception of 1996. However, the share of these revenues relatively decreased over the years from $49 \%$ to $46 \%$ because fees and charges have gained importance (see Figure 2). For Britain one can observe an increase in total revenues of over $85 \%$ in the period from 1990/91 to 2001/2002. They increased from about $€ 87$ billion to nearly $€ 160$ billion. As in Switzerland the absolute sum of tax revenues grew in Britain from $€ 33$ 
billion in $1990 / 91$ to $€ 50$ billion in $2001 / 2002$ but with a decrease in their share. The reason for this development can be seen in the pattern of the revenues from intergovernmental grants and transfers which more than doubled. While total revenues of municipalities in Poland amounted only to $€ 3$ billion in 1992, they substantially increased until 2002 to more than $€ 9$ billion. This corresponds to a three-fold expansion in ten years, which was triggered by the transformation process from a communist state towards political decentralisation and by the EU membership since 2004.

Figure 2: Structure of municipal revenues

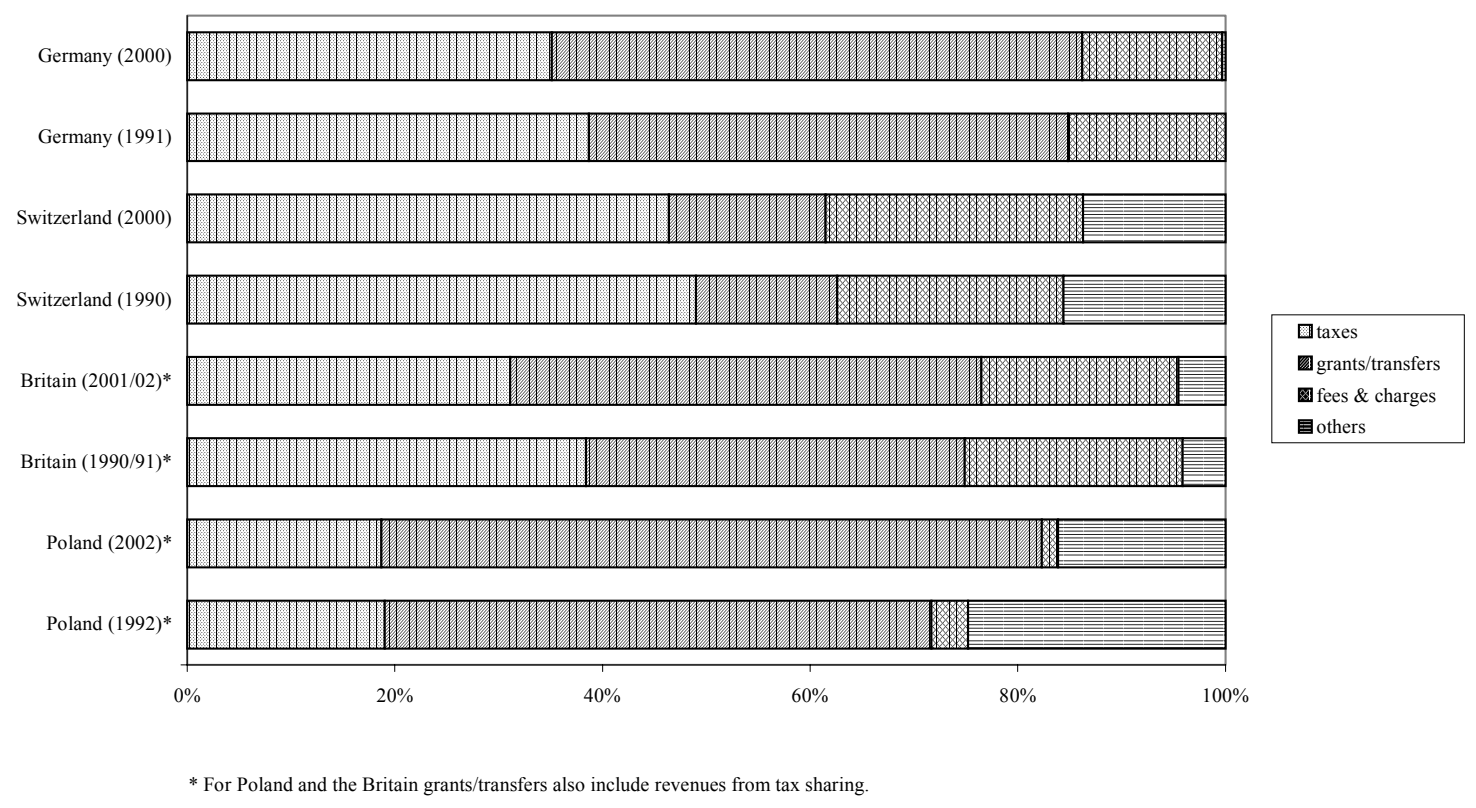

Source: Ifo Institute

German municipalities are strongly dependent on intergovernmental grants, which primarily serve to finance current expenditures in the fields of education, culture, social welfare, health, municipal public facilities and municipal firms and also partly assist in debt servicing and investment financing for local infrastructure projects. ${ }^{8}$ They increased by $65 \%$ from 1991 ( $€ 46$ billion) to 2000 ( $€ 76$ billion) with a peak in 1995 , where they amounted to $€ 78$ billion or nearly $54 \%$ of total revenues. In the following two years intergovernmental grants declined, as social welfare expenditures were re-

8 Investment grants remained relatively stable although the relation between current and investment grants has changed continuously in the western municipalities in favour of the former type. In the eastern part of Germany over $50 \%$ of all local revenues were based on grants due to lagging tax revenues. During the transformation process investment grants continually played an important role. Due to the reduction of expenses for services and the respective number of staff, outsourcing of services, privatisation, etc., current grants did not grow strongly in general. 
duced. ${ }^{0}$ But they started to rise again as of 1999 and grants reached a share of $51 \%$ of total revenues in 2000. Intergovernmental grants and transfers are also of great importance for the municipalities in Britain and Poland. In Britain they more than doubled in the period from 1990/91 ( $€ 32$ billion) to 2001/2002 ( $€ 73$ billion) and have presently reached a share of $45 \%$ of total revenues. This process was driven by the efforts to decentralise the country and to make each municipality economically more competitive. As the political responsibility of municipal governments has not been fully covered by the equivalent financial authority, the payment of grants is the only way to achieve this. The same reason holds for Polish gminas. Because of the communist regime only grants and transfers have been used in the preceding decades as an instrument to finance the necessary development of rural areas and to pursue the goal of fiscal decentralisation. So Poland experienced an increase in its share of grants and transfers from 53\% to $64 \%$ between 1992 and 2002. Although grants from central government and the respective cantons to municipalities in Switzerland also grew considerably in the 1990s, namely by about $76 \%$, there is a clear difference to other investigated nations: Swiss municipalities are not as dependent on them, and in 2000 only about $15 \%$ of total revenues were attributed to grants.

The dependence on grants can be seen in Figure 3 which illustrates the development of the share of own revenues over expenditures from 1990 to 2002 for the four countries. Important is the fact that own municipal revenues exclude grants and so the dependence of local authorities on grants is also implicitly shown.

9 This is the consequence of new regulations related to asylum seekers, health care for the elderly people, further outsourcing and service reductions, changes in legal forms of public facility activities and reduction in local investments. 
Figure 3: Fiscal dependence

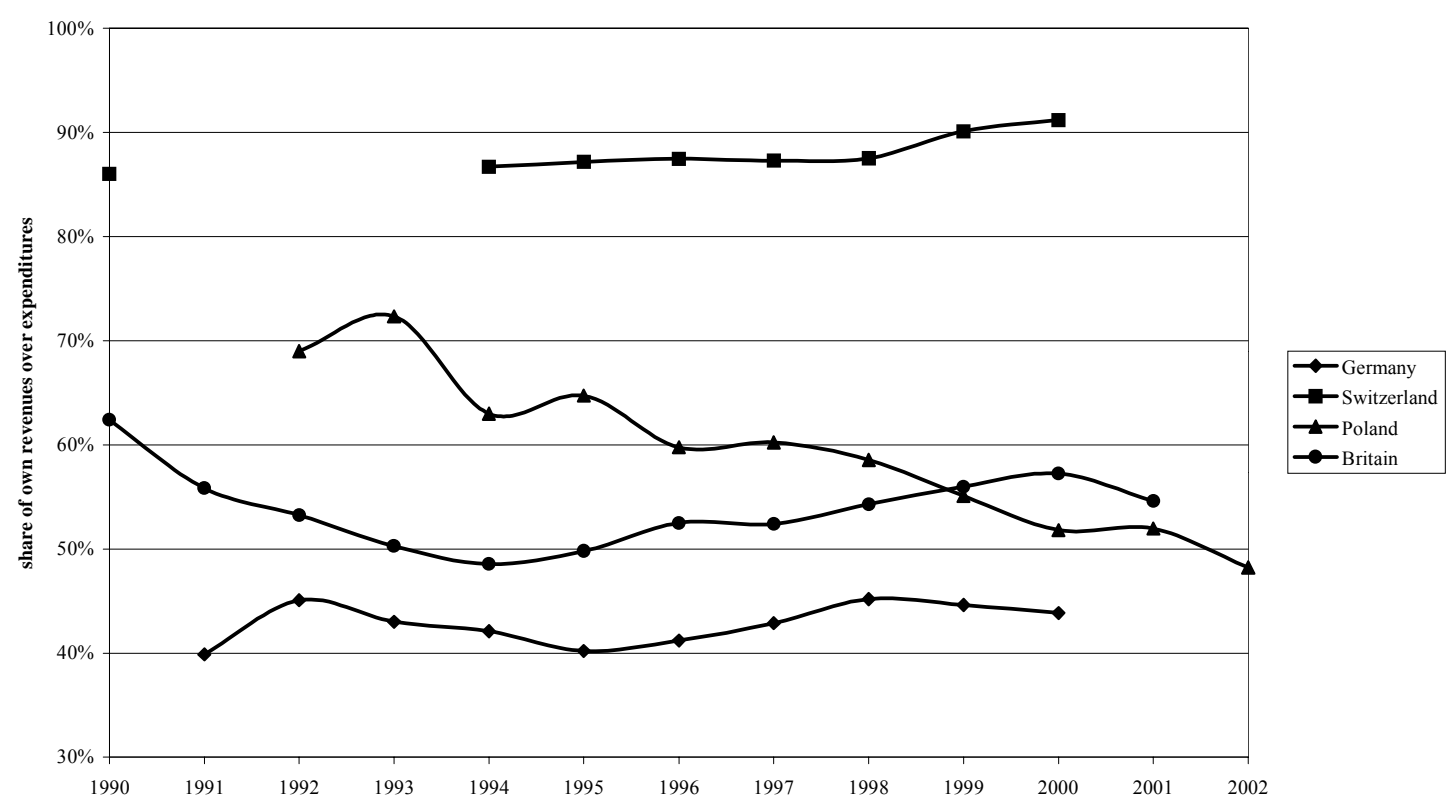

Source: Ifo Institute

Whereas for Swiss municipalities there is only a weak dependence on payments from the higher tiers of government, which has been decreasing since 1998, German, British and Polish local authorities are strongly depend on grants. One reason for the huge amount of grants for German municipalities in the 1990s is probably the transformation process of the former GDR. Therefore one tends to expect a sharp change in the extent of grant payments in the coming years, because the transformation process will be slowly 'completed'. But this is unlikely to occur, since German municipalities are entitled by law to receive financial resources (tax revenues and grants) for their tasks transferred from the state government. High grant payments are a typical consequence of this system and so German local authorities are not - in fiscal terms - fully autonomous. In contrast, the administrative and fiscal activities of Swiss cantons and municipalities are closely interwoven and the terms 'joint execution' and 'joint responsibility' are often used. This intensive co-operation at the cantonal and communal level is permitted by the federal and cantonal constitutions (Dafflon, 1999). Thus grant payments do not play a major role in Switzerland.

The reason for the increasing dependence of Polish municipalities on grants in the 1990s can be seen - as already mentioned - in the transformation process, which causes not only the privatisation of state owned firms but also the fiscal decentralisation of the country. This process will sooner or later come to an end. Furthermore, Figure 3 shows 
that municipalities in Britain also were strongly dependent on grant payments in the 1990 s, which reflects the dominant role of the central government in local finance matters. There is no sign that there will be a big change in the future in these two countries.

Regarding the development of municipal revenues from fees (and other current receipts) in Germany this item has been gradually decreasing since 1995, and in 2000 its share reached the level of 1992. This decrease can be attributed to the budget consolidation of western and eastern German municipalities which led to a reduction of personnel costs, the outsourcing of local activities, the establishment of municipal firms as well as the closing-down of institutions and privatisation. In contrast to Germany, revenues from fees have increased by $81 \%$ in Switzerland in the last decade. Current costs such as staff costs, material costs, interests or depreciation allowances have increased and so Swiss municipalities were forced to charge higher fees since they encountered difficulties in raising tax rates. Fees have gained importance in the last years, while tax revenues have become less important in Switzerland. In Poland the share of fees and charges decreased to less than $2 \%$ in the studied period. The transformation process accompanied by privatisation and closure of several firms has caused this reduction in Polish gminas.

As municipal expenditures will grow in the future - they have already done so in the last decade as already shown - municipalities will be forced to generate a new source of income. Because of the increasing tax competition in a further growing EU, tax increases are not easily enforceable. ${ }^{10}$ Furthermore there is little scope to enlarge grant payments since higher tiers of government have to stabilise their budget situation and fiscal autonomy will particularly not be ensured as long as municipalities are dependent on grants. Therefore municipalities opt to act like Switzerland and increase fees to meet expenditures. The development pattern of revenues from fees and charges in British municipalities also confirms this trend: Whereas the share of fees and charges in terms of total revenues decreased from $21 \%$ to $19 \%$ due to the above average increase in grant payments, the total amount of this item increased by about 67\% from 1990/91 to 2001/02. So in the future an increasing share of fees in Germany, Britain and Poland is anticipated as already happened in Switzerland.

10 The current discussion about a reform of the German tax system, the purpose of which is to simplify the existing fiscal system accompanied by decreasing tax rates for every income group, strengthen this argument. 


\section{Determination of Optimal Level of Fees}

\subsection{Normative Aspects of Determining Fees}

In previous years the issues on fees levied by local governments have not been adequately investigated by public finance experts, although there are some academic discussions on the principles of fixing fees (Bird, 1976; Seldon, 1977; Grossekettler, 1985; Wagner, 1991; Sacksofsky and Wieland, 2000). There are normative aspects related to the ways of determining fees to increase social welfare. According to a welfare function, the social marginal benefits of a public service should be equal to the marginal social costs of the same service. The social marginal benefits expressed in terms of willingness to pay for the service have to be equal to the marginal willingness to pay against the provision of the service, if the social net benefit concept is adopted instead of a welfare function. Such different types of willingness can be reflected in consumer surplus, sales, monetary terms for positive external effects subtracted by producer surplus, costs and monetary terms for negative external effects.

If the welfare expression is restricted to consumer surplus and sales subtracted by the related costs, the marginal cost pricing principle applies for fixing fees. With increasing marginal costs in a monopoly the amount of fee appears to be desirable, which satisfies the condition that the fee per service unit is the same as the corresponding marginal costs and, at the same time, allows profits (Oort, 1961; Lösenbeck, 1963; Nelson, 1964; Thiemeyer, 1964 and 1970; Krelle, 1976; Bös, 1981). In this case the application of peak load pricing is also possible (Turvey, 1971; Bätz, 1979; Blankart, 1980; Wirl, 1991). Sometimes institutional framework, organisational and legal forms require a balanced budget for the public institution providing the service. In cases with falling marginal costs the prices corresponding to marginal costs lead to losses, and the budget problems occur. For that purpose the so-called Ramsey-pricing (Ramsey, 1927; Bös, 1986), the Feldstein-prices considering cost coverage (Wirl, 1991) and the péage systems (Hutter, 1950; Boiteux, 1951; Allais, 1984) were developed for determining fees. In terms of cost effectiveness analysis fees are set to cover the cost required for the delivery of maximal output (Friedrich, 1969; Krelle, 1976). In the utility analysis, on the other hand, fees are determined under the consideration of maximising sales and receipts from concessions (Friedrich, 1969), employment maximisation (Hansmeyer and Fürst, 1968; Bös, 1986), regional economic goals (Thiemeyer, 1975) and vote maximisation (Blankart, 1980; Ziemes, 1992). The so-called commercial-pricing offers the rules that can also be welfare-oriented (Shepherd, 1965; Friedrich, 1969). However, these principles do not consider whether the determination of fees is related to central government, state or municipal government. 
The conventional welfare-oriented literature on fees mainly examines the welfare maximisation of the central government for the entire nation, taking into account the willingness to pay on the part of all the citizens (Friedrich, 1971). The welfare of a substate in a federation or a municipality cannot be easily detected through the net benefit approach, since prices do not only reflect the willingness to pay of people in the state or municipality investigated. For instance, consumer surplus, turnover, producer surplus, etc. show the judgements of non-state or non-municipal residence, commuters and also people from abroad. The benefit-cost analysis, oriented to the isolated welfare maximisation of a sub-state or a municipality, makes an evaluation in monetary terms possible. Sales, consumer surplus, costs etc. have to be re-defined and special deferrals have to be made. Sales to non-residents can be interpreted as exports, and procurements from nonresidential citizens and economic units can be classified as imports. A willingness-touse indicator for export surplus, taxes from other residence etc. may be developed as well. Many more changes must be introduced in the evaluation schemes (Friedrich, 1971). When determining the optimal size of fees, quite different marginal costs and marginal benefits emerge, and the marginal cost pricing produces other values than the average fee equal to the state or municipal relevant costs. Therefore, the welfareoriented fee determination does not deliver satisfactory guidelines to find the optimal level of fees.

Moreover, researchers assume monopolistic market forms to determine fees for the supply of municipal services. This is true in some exceptional cases like a marriage license bureau. However, one quite often finds oligopolies such as convention halls, theatres, swimming pools, municipal garbage plants, municipal banks, or oligopsonies like business promotion agencies. The monopolistic competition can emerge or there are near polypolies, for example, if schools can be chosen by parents. Marginal cost pricing is also mainly related to the oligopolies. Often other parameters of action, such as service times, are not considered in welfare-oriented approaches (Friedrich, 1978). For the formation of fees the whole range of sales instruments and production management should be considered. Thus the welfare-oriented fee determination does not provide satisfactory guidelines to find an optimal level.

Those fee-collecting public institutions, such as administrative units and public enterprises, can have many organisational forms of public and private laws, which also prescribe different regulations for the formation of fees. Therefore, there are actually very different pricing policies allowed, which range from acceptable (not maximal) profits for public enterprises to substantial losses in order to promote the receipt of services (theatres, etc.). Moreover, the fee-collecting public economic units and their pricing policies are used as instruments for economic policy-making (Oettle, 1998) or as instruments for promoting regional competition (Friedrich and Feng, 2000). Munici- 
palities can also try to create profits and revenues to consolidate their budget in the framework of legal possibilities, or they may follow political aims such as winning votes (Thiemeyer, 1975). Therefore, a bundle of different goals may underlie the formation of fees.

A municipality can also establish a local enterprise of public or private law to provide services. Then the municipality may try to receive gains from the public enterprise in the framework of legal possibilities. If it happens in the form of public law, legal requirements for cost coverage exist (Zwehl, 1991; Gawel, 1995; Gottschalk, 1998; Siekmann, 1998; Tettinger, 1998; Färber, 2000; Rehm, 2004). However, due to the autonomy to shape the cost-accounting scheme and the consideration of costs not leading to financial outflows like imputed cost for depreciation (Zimmermann, 2003) or nonrealised risks, wages for entrepreneurial management, etc. and the application of different cost assessment and distribution methods, fiscal receipts can be gained (Friedrich, 1998; Wienbracke, 2004). Although municipal firms of private law underlie cost coverage pricing requirements (Tettinger, 1998), their legal possibilities for achieving profits are larger. Therefore fees can be determined by the special principal-agent relations as well.

Nowadays the private public partnership is developed especially on the local level. Here many legal solutions seem to be possible (Gottschalk, 1998). Fees can be collected by a municipality, whereas production and distribution of services may be organised by a private enterprise selling its services to the municipality. In this case the level of fees strongly depends on the type of contract made between the local government and the private firm and on higher or lower costs occurring to the private firm, as well as on the legal requirements, such as laws related to public procurement and price-setting between the two parties mentioned above.

In order to limit the number of objectives to be achieved when fixing fees, some requirements are legally suggested. In Poland and Germany the benefit principle is applied in the form of cost-coverage requirements (Borodo, 2003; Bohley, 2004). In Germany similar state laws exist that regulate the fee determination of municipalities (Siekmann,1998; Tettinger, 1998). In Switzerland it is up to the regulations of the individual cantons to determine how municipalities charge for local services. In Britain there are many different regulations with respect to charging for public services. Whether those normatively based user-charge policies improve the fiscal situation of municipalities depends on whether loss avoidance or profits are possible or probable. To examine this possibility a positive theory for fee levying administrative units and public enterprises should be developed. 


\subsection{Positive Theories of Fees}

Public administrative units (public office) charging fees attempt to achieve public goals by providing goods and services to other economic units (e.g. businesses and consumers). They possess the long-term stock of production factors and their management should be competent regarding the essential decisions related to production and delivery. Public offices comprise legally dependent institutions fully integrated into the budget planning. Fees are normally not for direct disposal of such an administrative unit.

A public firm is separated from the owner's budget planning (Eichhorn and Friedrich, 1976). Such a firm shows some characteristics similar to a private firm, since they are also oriented to sales and markets (Friedrich, 1969 and 1992; Rees, 1976; Turvey, 1971; Thiemeyer, 1975; Blankart, 1980; Bös, 1981; Püttner, 1985; Mühlenkamp, 1994). On the other hand it is obliged to achieve public goals, which are fixed by an owner, by a regulatory agency or by law, or which are determined within the decision-making units of the public enterprise. Some public enterprises are subject to special fee regulations prescribed in state and national laws or the pricing policy guidelines of the firm owners.

\subsubsection{Standard Fee Determination for a Municipal Firm}

A simple model of a public firm serves as a basis for a theory of public firms and makes it possible to integrate many aspects of fee policies into the model. The following model of a public firm comprises (Friedrich, 1992 and 1998; Friedrich and Feng, 2000):

- A utility (goal) function U of the public firm's management showing management utility dependent on output $\mathrm{X}$ and labour input $\mathrm{L}$.

$$
\mathrm{U}=\mathrm{U}(\mathrm{X}, \mathrm{L}), \quad \partial \mathrm{U} / \partial \mathrm{X}=\mathrm{U}_{\mathrm{X}}^{\prime}, \quad \partial \mathrm{U} / \partial \mathrm{L}=\mathrm{U}_{\mathrm{L}}^{\prime}
$$

- A restriction concerning the production function. There is one fixed factor A and two variable factors of production, $\mathrm{L}=$ labour and $\mathrm{C}=$ materials.

$$
\begin{gathered}
X=A \cdot f(L, C), \quad \begin{array}{c}
\partial f / \partial L=f_{L}^{\prime}>0 \\
\partial f_{L}^{\prime} / \partial L=f_{L}^{\prime \prime} \leq 0
\end{array}, \quad \begin{array}{l}
\partial f / \partial C=f_{C}^{\prime}>0 \\
\partial f_{C}^{\prime} / \partial L=f_{C L}^{\prime \prime}=f_{L C}^{\prime \prime}=\partial f_{L}^{\prime} / \partial C=0
\end{array},
\end{gathered}
$$


- A demand function shows the dependency between price $\mathrm{P}$ and volume $\mathrm{X}$ of output sold

(3) $\quad \mathrm{P}=\mathrm{P}(\mathrm{X}), \quad \partial \mathrm{P} / \partial \mathrm{X}=\mathrm{P}^{\prime}<0$

- The cost function demonstrates fixed costs $\mathrm{K}_{\mathrm{A}}$ and two types of variable costs. The factor price of labour is $\mathrm{w}$ and that of materials is $\mathrm{i}$.

(4) $\quad \mathrm{K}=\mathrm{K}_{\mathrm{A}}+\mathrm{w} \cdot \mathrm{L}+\mathrm{i} \cdot \mathrm{C}$

- A restriction, according to which sales turnover is the same as costs, is introduced. We assume self-financing of the public firm.

$$
\mathrm{P}(\mathrm{X}) \cdot \mathrm{X}=\mathrm{K}_{\mathrm{A}}+\mathrm{W} \cdot \mathrm{L}+\mathrm{i} \cdot \mathrm{C}
$$

- Maximisation of utility of management under the restrictions mentioned above leads to the following Lagrange equation:

(6)

$$
\Lambda=\mathrm{U}(\mathrm{X}, \mathrm{L})+\lambda \cdot\left(\mathrm{P} \cdot \mathrm{X}-\mathrm{K}_{\mathrm{A}}-\mathrm{w} \cdot \mathrm{L}-\mathrm{i} \cdot \mathrm{C}\right), \quad \text { while } \quad \mathrm{X}=\mathrm{A} \cdot \mathrm{f}(\mathrm{L}, \mathrm{C})
$$

The following first-order conditions of maximisation are delivered,

$$
\begin{aligned}
& \frac{\partial \Lambda}{\partial \lambda}=\mathrm{P}(\mathrm{X}) \cdot \mathrm{X}-\mathrm{K}_{\mathrm{A}}-\mathrm{W} \cdot \mathrm{L}-\mathrm{i} \cdot \mathrm{C}=0, \\
& \frac{\partial \Lambda}{\partial \mathrm{L}}=\mathrm{U}_{\mathrm{L}}^{\prime}+\mathrm{U}_{\mathrm{X}}^{\prime} \cdot \mathrm{A} \cdot \mathrm{f}_{\mathrm{L}}^{\prime}+\lambda \cdot\left[\mathrm{P} \cdot\left(1-\frac{1}{\varepsilon}\right) \cdot \mathrm{A} \cdot \mathrm{f}_{\mathrm{L}}^{\prime}-\mathrm{w}\right]=0, \quad \text { while } \quad \varepsilon=-\frac{\mathrm{P} / \mathrm{X}}{\mathrm{P}^{\prime}} \\
& \frac{\partial \Lambda}{\partial \mathrm{C}}=\mathrm{U}_{\mathrm{X}}^{\prime} \cdot \mathrm{A} \cdot \mathrm{f}_{\mathrm{C}}^{\prime}+\lambda \cdot\left[\mathrm{P} \cdot\left(1-\frac{1}{\varepsilon}\right) \cdot \mathrm{A} \cdot \mathrm{f}_{\mathrm{C}}^{\prime}-\mathrm{i}\right]=0,
\end{aligned}
$$

which yield two optimality conditions. One concerns the equivalence of the relation of marginal utilities of marginal factor-inputs to the proportion of respective marginal profits and the other condition refers to cost coverage of turnover.

$$
\frac{U_{L}^{\prime}+U_{X}^{\prime} \cdot A \cdot f_{L}^{\prime}}{U_{X}^{\prime} \cdot A \cdot f_{C}^{\prime}}=\frac{W-P \cdot\left(1-\varepsilon^{-1}\right) \cdot A \cdot f_{L}^{\prime}}{i-P \cdot\left(1-\varepsilon^{-1}\right) \cdot A \cdot f_{C}^{\prime}}
$$




$$
P=\frac{K_{A}+w \cdot L+i \cdot C}{X}
$$

Corresponding to the various utility functions, different cost curves emerge. An outputmaximising public firm shows the curves of minimal costs. If output and labour are evaluated positively, then a curve of higher costs results. If only labour has a positive weight is the cost curve more unfavourable, and if management needs labour compensation in case of higher production, the cost curve is located even far higher.

The restriction may also refer to a given desired profit requiring a given difference between turnover and costs. However, the results do not change fundamentally. The result of the model is shown graphically in Figure 4. The second quadrant demonstrates the sales conditions of the public firm. For each volume of sale a turnover and the referring financial revenues are generated that are used to cover costs. After deducting fixed costs $\mathrm{K}_{\mathrm{A}}$ a cash flow is available to finance variable costs. The so-called output-labour curve illustrates all output labour combinations that can be financed. However only one production volume $\mathrm{X}$ corresponds to each sales volume, therefore only two points on the output-labour curve shown in the second quadrant are relevant. One production is material-intensive and the other one is labour-intensive. For alternative turnovers and corresponding production volumes a set of output-labour curves and a set of relevant material-intensive and labour-intensive points result. Their connection leads to a frontier of production possibility on the labour-output curve indicated as a thick curve in this quadrant. Introducing a set of indifference curves that correspond to the management utility function (1), the highest indifference curve that the management can achieve touches the frontier of production possibility on the output-labour curve at point $F$. This determines the optimal production volume A, the optimal price B and the optimal turnover D. Moreover, there is a path of tangency points between alternative possible output-labour curves, which correspond to alternative demand curves of the public firms. They are related to the cost curves mentioned above. 
Figure 4: Theory of the public firm

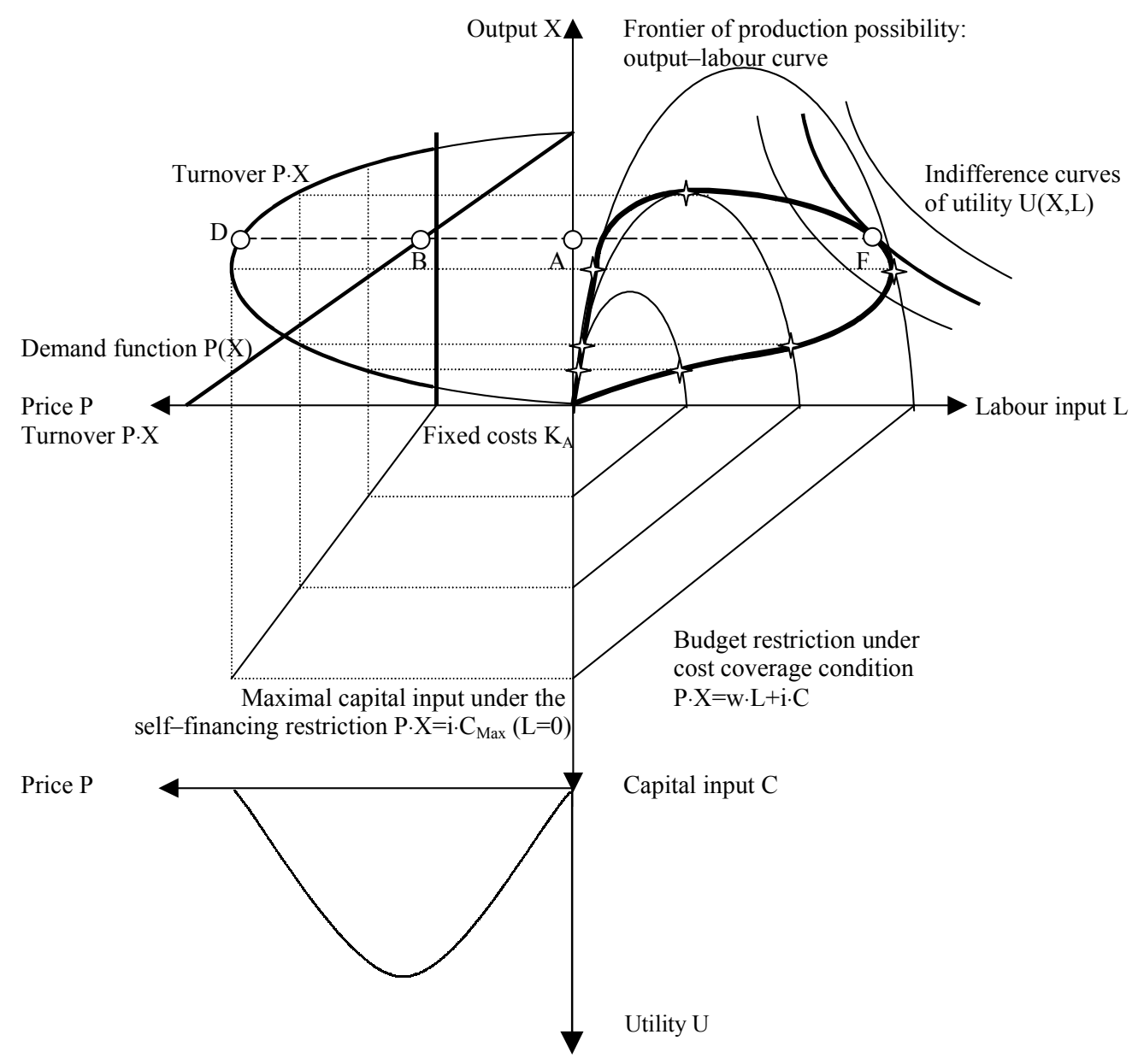

If the management utility function depends on output only, management maximises output (Type II) and the (cost-minimising) cost function results. Utility functions depending on output and labour (Type I) lead to paths more to the right of the cost minimal path in the right hand quadrant. If the public firm is going to maximise labour input (Type III) then a path emerges, which connects those tangency points near the respective maximal turnover volumes. If the utility function (1) depends on profit and the restriction (2) is not binding but just a profit definition, then we end up with a maximum profit (Type IV) solution along the cost minimal path. In rare cases the owner of public enterprise tries to use its public firm to raise local revenues (Friedrich, 1998; Friedrich and Feng, 2002). The respective solution would, in turn, lead to a higher price and a smaller output than former solutions. A utility function depending on profit and labour (Type V) results in a solution between the profit maximal and the labour maximal price. The related output and fee solutions are illustrated in Figure 4 and Figure 5. 
Figure 5: Solutions according to types of management
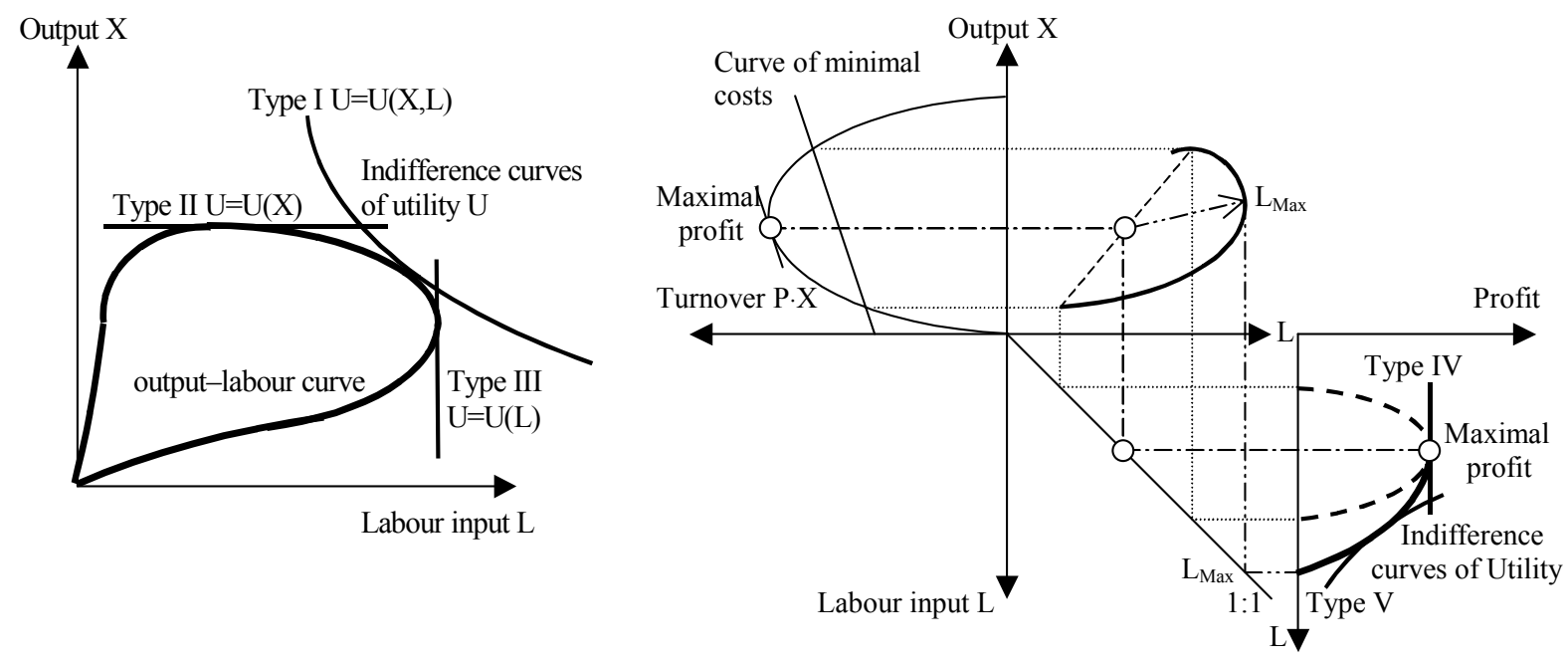

\subsubsection{Determination of Fees According to Investment Rules}

The fee level can also be found by the application of investment rules (Friedrich, 1969). In Figure 6 different fee sizes of a charging public firm are shown, and the resulting cost curve and the turnover curve are depicted. Because of the positive evaluation of output (output maximisation or output- and labour-dependent utility maximisation as mentioned above), the intersection of turnover and the cost curve turns out as the solution for determining output and price. For a given utility function of management the better solution allowing the higher output level is located always to the right. The point and respective output where the location-oriented cost curves cross is called the critical output.

Hence we can derive the following rules for user charges of the public enterprise (see Figure 7):

- If the critical output can be sold at profit, the production process is the best where the relevant cost curve shows the lower marginal costs than another one.

- If the critical output that is smaller than that at maximal turnover cannot be sold at profit, the production process with the lower marginal costs is the best one.

- If the critical output that is bigger than that at maximal turnover cannot be sold at profit, the production process with higher marginal costs is the best one. 
Figure 6: Fees corresponding to different sizes of public enterprise

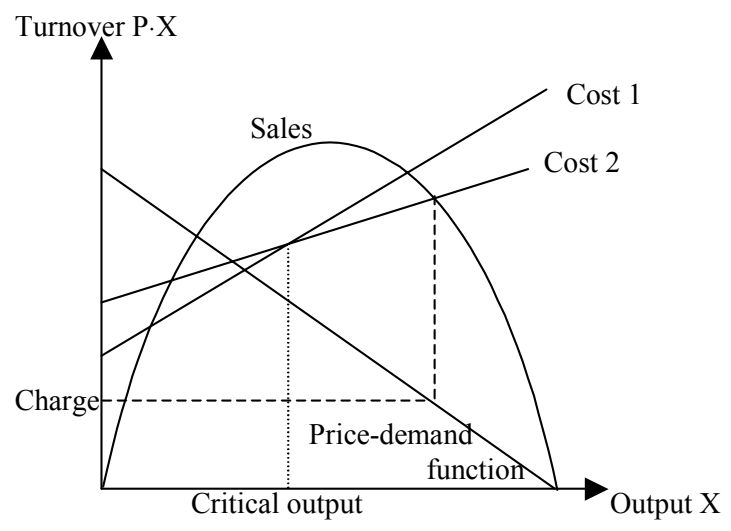

The solution illustrated in Figure 5 can also be applied if a required absolute profit has to be achieved. The cost curves get marked up by the profits and the rules apply to the resulting curves.

\section{Figure 7: Different fees according to different critical outputs}
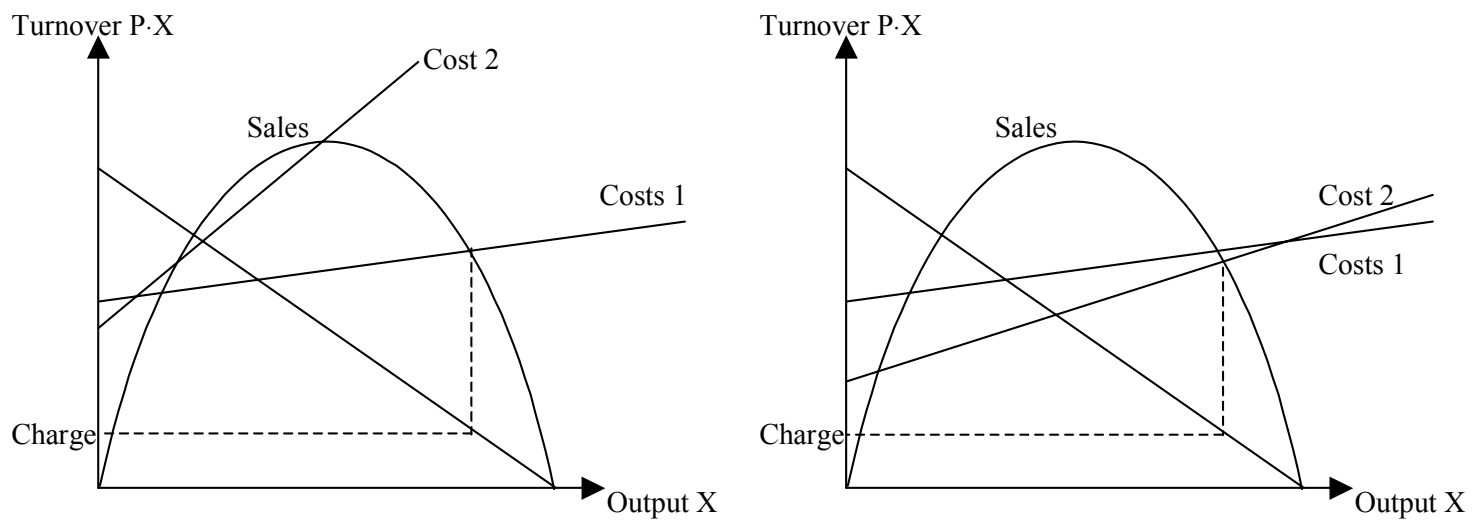

\subsubsection{Negotiation Solution between Management of Public Firm and Local Gov- ernment as Owner}

The model introduced above is useful as well if there is another decision-maker at a higher level, such as the owner government, who has a utility preference function concerning the output and the financial means. For the initial attempt we consider the owner government a very powerful principal, e.g. the management of the public firm needs additional financial means from the owner, the legal form of the public firm guarantees high competence of the owner government, etc. It is able to command the man- 
agement of the public firm serving the principal as an agent. However, it should not totally lose the co-operation of the public firm's management, for this management is needed to realise the location choice. Therefore, the public management of the firm has to receive a minimum utility to guarantee their willingness to perform.

This approach was applied to determine actions of municipal competition through local enterprises (Friedrich and Feng, 2000). The utility function of the public firm is again dependent on output and labour. But now a profit is allowed, which is transferred to the municipality. The utility function of the municipality shows utility depending on the output of the firm and on the profit transfer. Moreover, minimum utilities are introduced for both players. For the given demand and production functions there are combinations of Pareto-optimal profit and output level from which a solution should be chosen. These combinations also lead to the combinations of utilities, forming a utility frontier. The best solution in favour of the powerful principal is where the principal receives its maximum utility and the public firm achieves minimum utility.

However, the principal may not be as powerful as mentioned above for various reasons. These can include, for example, (a) dependencies of the local economy on the services and goods produced by the municipal firm (in areas of electricity, transportation, water supply, tourism and culture, etc.) or the knowledge and skills of the management of the public firm, and (b) a favourable relation of the management of the public firm to the management of a municipal savings bank or mutual political support. Then the players have to negotiate to find a solution including a combination of utilities and of output and profits. However, there is a consequence of such solutions, depending on the location, which again forms an own utility frontier, from which a Nash solution can be derived giving the fee level of the public enterprise.

\subsubsection{Model Including Political Determinations}

Furthermore models may refer - on the part of the principal - to political goals such as winning elections or maximising votes. If the model developed by Pelzman (1971 and 1976) and Ziemes (1992) is adapted to our theory of public firm (see Figure 4) the principal is interested in vote maximisation whereas the public firm tries to maximise utility. However, this model also concerns price policies and tackles price-setting in two markets referring to different voters. ${ }^{11}$ We investigated one public enterprise that sells in

11 With Peltzman (1971 and 1976) and Ziemes (1992) not utility but profit is maximised by the public firm. Although the profit maximisation is generally restricted for public enterprises (Friedrich, 1969; Püttner, 1985; Detig, 2004), some public enterprises (especially in the industrial sector) try to achieve such goals. Then the $U$ curves are utility curves of the management of the public enterprise if imputation of the fixed costs to the productions are given. Formally our solutions are the same as that of Ziemes (1992), but the management utility is used instead of profits (see Figure 12). If there is no pre- 
monopolistic markets (Feng and Friedrich, 2004). The utility of the public enterprise increases with the price reductions until a utility maximum is reached but decreases when price cuts continue. This is demonstrated in Figure 8 by curves U1 and U2 referring to the different levels of utilities. Indifference curves that reflect price combinations are derived. The curve $\mathrm{P}$ shows all price combinations that yield the same utility.

\section{Figure 8: Utility indifference curves}

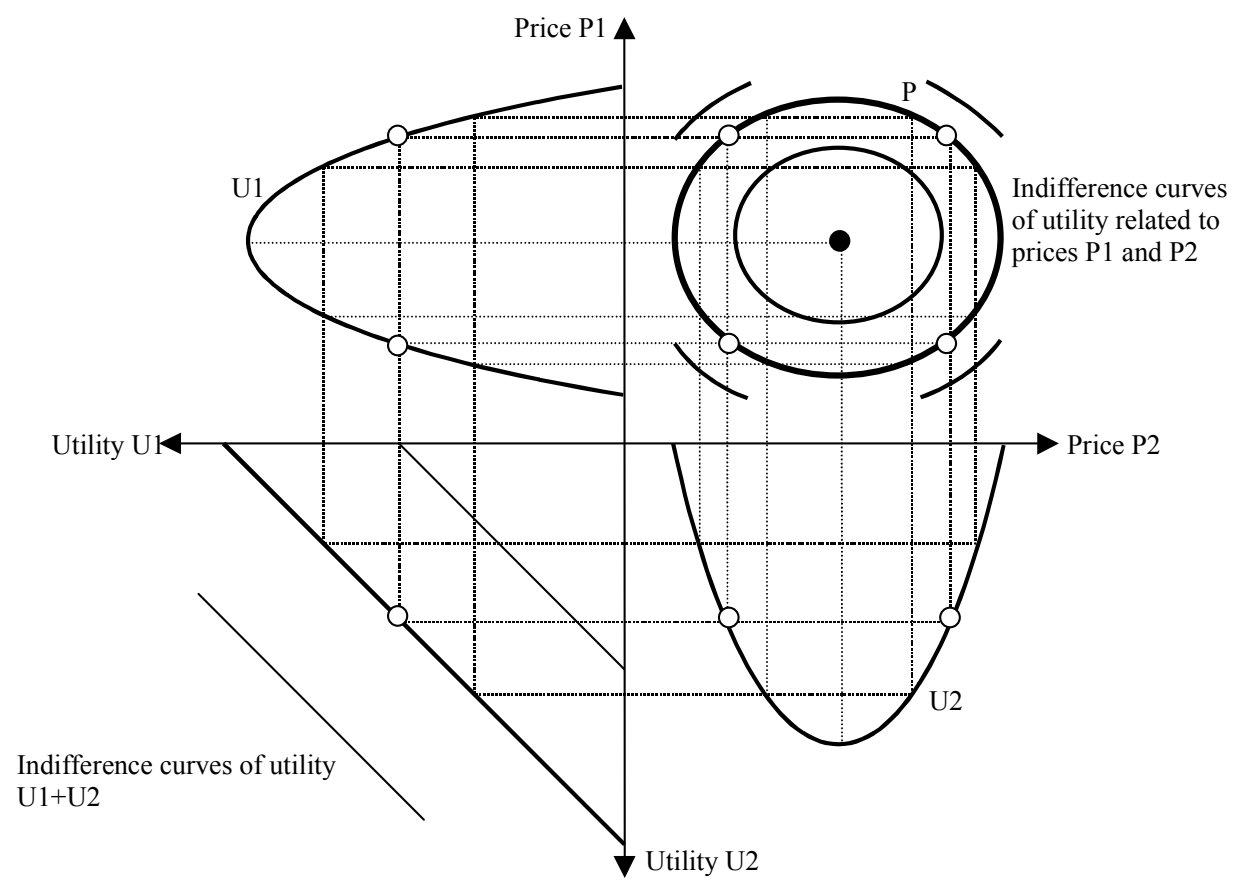

Voters dislike high prices of public enterprises. Therefore, the curves A1 and A2 result with respect to votes in Figure 9. For votes a curve $\mathrm{V}$ is delineated that shows all price combinations at both markets of public services leading to the same amounts of votes.

Points of tangency between the curves V and P in Figure 10 show a path of Paretooptimal combination of prices ZM for the principal (political interested owner) and the agent that give maximal utility at given votes or maximal votes at given utility. The respective combination of utilities are shown in Figure 11, in which the votes are depicted vertically and the utilities horizontally. If a very powerful principal (owner) is assumed, he determines a low utility (eventually zero) and a maximum of votes in point $\mathrm{Z}$. If the agent is overwhelmingly powerful he asks for his maximum utility at point $\mathrm{M}$ leaving the principal with the resulting votes. We can introduce the minimum utility in order to ensure the activities of the public enterprises or the minimum votes for the 
principal necessary to avoid privatisation etc. Again a Nash solution can be achieved at point N. In this case the political influence of the owner leads to relatively low prices.

\section{Figure 9: Indifference curves of votes}

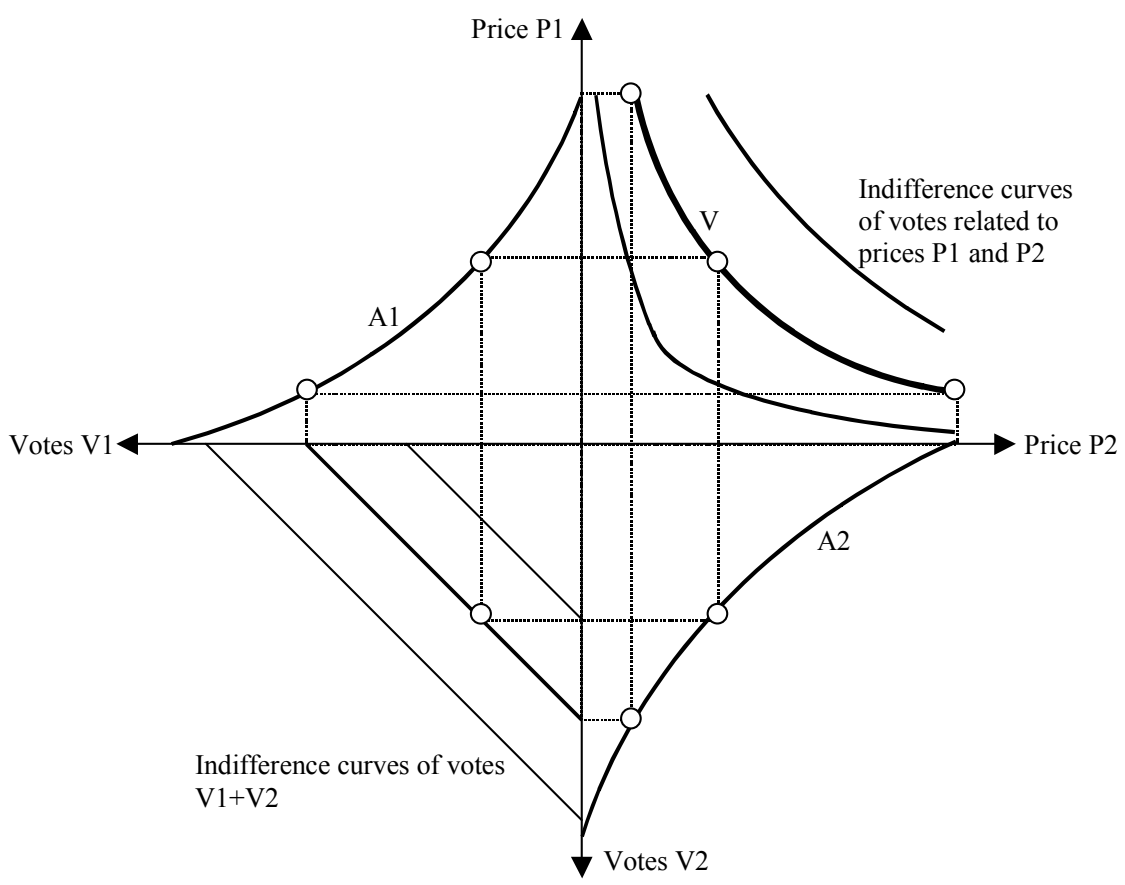

Figure 10: Pareto-optimal path of fees

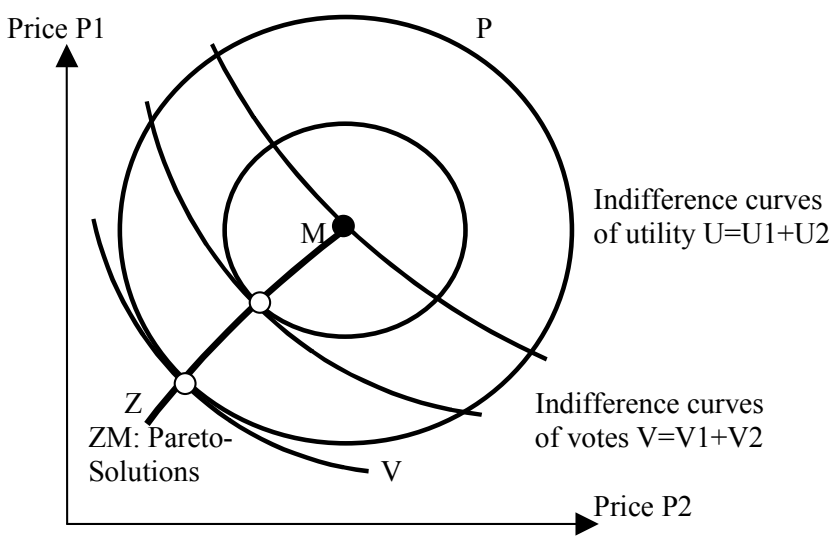


Figure 11: Nash-solution for fees

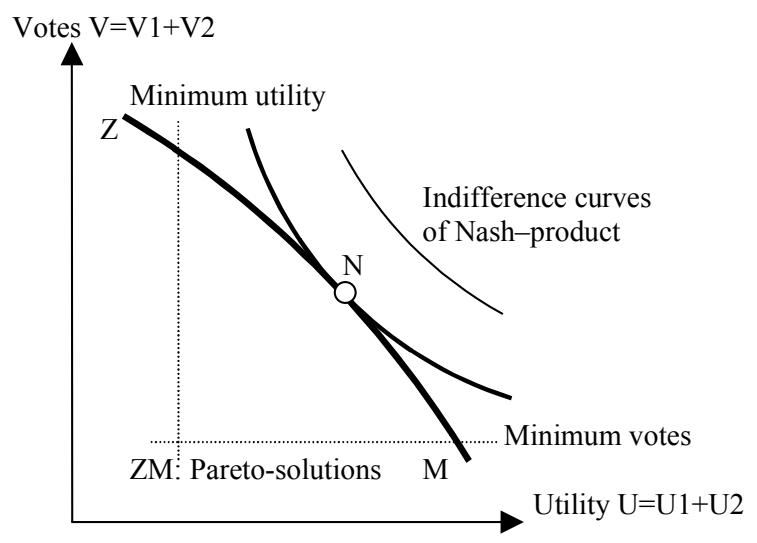

\subsubsection{Model Considering Regional Competition}

However, if the public enterprises compete against each other as well, the payoff is additionally determined by a duopoly solution embedded in the model above (Friedrich, 1988). For one competitor the solution above is determined for a given fee of the competitor (Friedrich, 1998) $\stackrel{12}{5}$ Following this assumption a Launhardt-Hotelling solution can be elaborated yielding the payoffs. The solutions of the duopolies and municipal competition can also give other results related to employment, price, output, vote, use of land etc. A double - two-level - regional competition among municipalities owing public enterprises and charging fees and the direct competition among the fee collecting municipal enterprises can also be modelled (Friedrich, 1998; Lindemann, 1999).

As the horizontal competitive solutions are so difficult to model, we may choose a different modification of our theory. We use the principal-agent version of our model and refer to the monopoly case. But we introduce a competitive situation $\mathrm{W}$ of the municipality and the valuation of the financial target described as $F$ is expressed by $g_{F}(W)$ - see Figure 12. The municipality and the municipal enterprise negotiate about fixing the financial scope $\mathrm{F}$ as well as the volume $\mathrm{X}$ to be produced and the fee $\mathrm{P}$ to be charged. The utility of municipality $\mathrm{U}_{\mathrm{G}}$ depends on output $\mathrm{X}$ (or votes depending on output) and its contribution $F$ to the municipal budget $\left(\mathrm{U}_{\mathrm{G}}=\mathrm{X}+\mathrm{g}_{\mathrm{F}}(\mathrm{W}) \cdot \mathrm{F}\right)$. The utility of management of the public firm $U_{U}$ depends on output $X$ and employment L. Both negotiators want to realise, each for himself, a minimum utility level. The situation of the

12 If there are two competitors a sequence of optimal fees results according to the fees determined by the competitor. This corresponds to a reaction function of the competitor related to P1 and P2. The socalled Launhardt-Hotelling solution is achieved where these functions of the competitors intersect against each other. 
firm shows production, demand, cost and finance functions. As derived above an area for possible negotiation solutions referring to financial contribution, the output volume $\mathrm{X}$, the fee, and the respective utilities of the negotiators are determined. By bargaining according to the Nash a solution is found and the fee is again determined (Figure 12).

\section{Figure 12: Fees in case of regional competition}
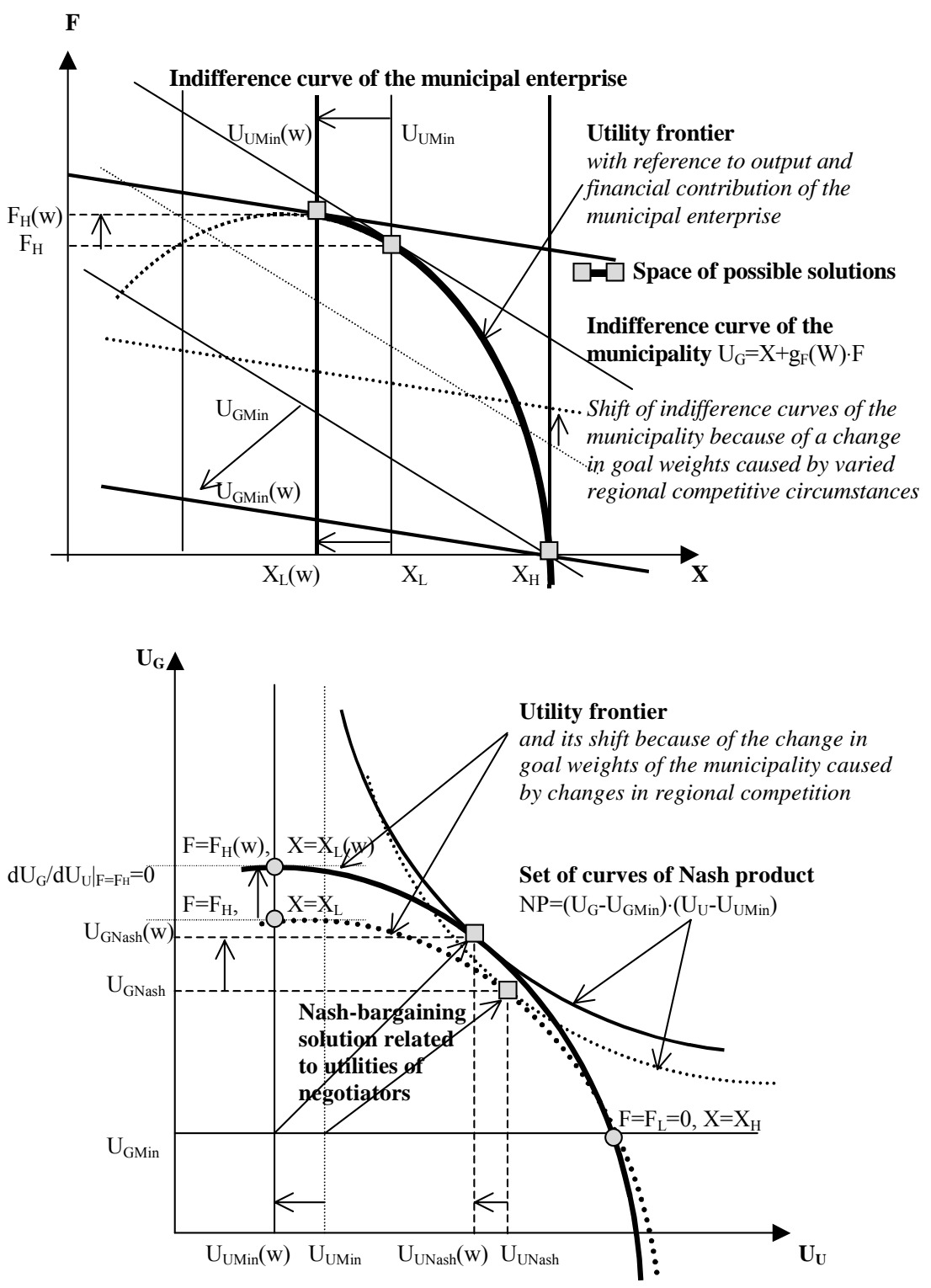

If the financial contribution is of high importance, then $\mathrm{g}_{\mathrm{F}}(\mathrm{W})$ also turns out to be high. If the competitive pressure $\mathrm{W}$ on the municipality is high, it requires high financial contributions from public firms, for example, casinos, lotteries, trade fair companies, etc. The owner tries to apply a high price policy mostly against the desire of the public 
firm. If the municipality uses the public enterprise directly for competitive purposes such as with real estate companies, business promotion agencies or in direct infrastructure or industrial competition such as wineries, farms, manufacturing firms or holiday resorts, sports facilities, municipal tourist firms etc., a higher $\mathrm{W}$ in turn leads to a smaller $\mathrm{g}_{\mathrm{F}}(\mathrm{W})$. A tendency to a lower financial contribution leads to higher outputs and lower fees.

\section{Concluding Remarks on Increase of Municipal Fiscal Autonomy through Fees}

The development of municipal public finance during the last decade demonstrates that (a) municipal expenditures have been rapidly growing in European countries but local tax increases are not easily enforceable anymore, (b) central government interventions with grants have intensified, (c) municipalities have been forced to carry out budget consolidation caused by the fiscal stress, while they have experienced a reduction in fiscal autonomy at the same time.

Some serious attempts appear to be necessary to help local governments in order to ensure their fiscal autonomy. One possibility would be the increase in fees as the local revenue source. The concerns over the distortionary effects of tax financing, fairness and a desire to make costs more perceptible to consumers are all factors that potentially support increases in the scope of user charges. In previous years the issues on fees levied by local governments and their optimum sum have not been adequately investigated by public finance experts.

The different aims underlying municipal fee policies signal the dependence of fee formation on the various possible goals. Thus various factors determine the level of fees, such as a welfare function, consumers' willingness to pay, sales, costs, willingness to pay in favour or against external effects, the jurisdictional levels like the EU, the nation, the region, a municipality, indicators for success in competition such as market shares, outputs, indicators as employment, production, migration, centrality of a municipality, growth rates, budget sizes, political indicators such as number of votes, shared jobs by party members, staffing politically important posts, and many indicators to show administrative success, such as the number of beds in hospital, square meters of cleaned roads, number of pretended cases of crime, school children, and tourists, tons of water supply, etc. or environmental indicators such as tons of waste, volume of $\mathrm{SO}_{2}$, $\mathrm{CO}_{2}$, etc. Therefore, according to the various goals quite different fees can result, although in some countries the benefit principle should be applied in practice. Mostly the benefit principle is interpreted as cost coverage principle. However, there are some ex- 
ceptions, thus for some fees this principle is merely a guideline. For example in Germany a profit should be small and less than 14\% above costs (Rogosch, 1988). On the other hand, deficits are allowed or tolerated to better achieve environmental, educational or social aims. Moreover, cost coverage does not imply a well-defined principle. As municipalities have organisational autonomy and the laws concerning fee formation are not very clear, costs can be defined in different ways. For instance municipalities are able to control costs within their types of costs accounting - departmental costs accounting or their own cost unit accounting (Friedrich, 1998). As a consequence, they can allocate their costs according to their aims to result in high or low fees.

The approaches in positive theory of fixing fees show us that additional factors play a role. The aims and utility functions of management and owners lead to different fees. Not only the situations and market forms in vertical and horizontal competition connected with the public firm but also (regional and) municipal competition are relevant. Apart from pricing policies the fixing of other parameters of action by administrative units and public firms can also cause quite different fees. Moreover, types of production functions, requirements concerning management organisation, factor prices, budget distribution systems, taxation, subsidisation, legal forms of public firms or public administrative units, and local statues and laws determine the fees as well.

Compared to the fiscal situation in which all other modes of finance and the volume of revenues are given, a budget increase can be achieved when the formation of fees with respect to providing a fixed amount of services is possible. This also applies even if the turnover resulting from the fees does not cover cost. However if the municipality can choose the output of services and provide a higher volume of services than before, the inherent loss may lead to a shrinking budget. As far as legal requirements force the municipalities just to cover costs, their fiscal autonomy cannot be significantly improved by collecting fees. Insofar as they allocate costs adequately in the course of their cost assessment, their fiscal situation may be enhanced by causing hidden profits. If no losses occur, fiscal autonomy is widened by financing higher volumes of municipal activities with user charges. Moreover, the fiscal situation of a municipality may be improved by avoiding losses with appropriately higher fees. When a municipality is able to achieve reasonable non-maximal profits, it can improve its fiscal autonomy. In cases where municipalities are free to set fees, profit transfers may lead to sustainable improvements of fiscal autonomy. Fees can also improve fiscal autonomy if projects and productions are jointly financed by the municipality and other authorities, for such a cooperation enables the local government to contribute its own financial share more easily. Through the provision of charged services the municipality may additionally be able to acquire conditional grants thus increasing fiscal autonomy. Moreover there may be 
restrictions on public debts which can be eased in case of local activities related to financial receipts through fees.

Therefore, municipalities should be careful in selling their public firms or outsourcing their own production. The basis for fee financing is public property and public production. In the case of privatisation the benefits from fees are transferred to the private sector, and it is not guaranteed that private production will lead to higher municipal revenues or even smaller costs. Often, additional tax revenues from private owners are not expected as those fee-collecting institutions are often taxed like private firms in taxation. They are subject to sales taxes and other taxes like business tax, corporate income tax, real estate tax etc. If the municipalities give up their production and sell their public firms, a control of the local (regional) economy is less effective. Therefore, policy-making to improve the fiscal autonomy becomes more difficult.

\section{References}

Allais, M. (1984), Le Problème de la Coordination des Transports et la Théorie Economique, Revue d'Economie Politique 58, pp. 212-271.

Bätz, K. (1979), Administrierte Preispolitik öffentlicher Unternehmen, Gebühren und Tarife als Mittel zur Lenkung der Nachfrage nach öffentlichen Leistungen, BadenBaden: Nomos.

Bird, R. (1976), Charging for Public Services, Toronto: Canadian Tax Foundation.

Blankart, C. B. (1980), Ökonomie der öffentlichen Unternehmen, München: Vahlen.

Blankart, C. B. and R. Borck (2003), Local Public Finance, http://www.polecon.de.

Bös, D. (1981), Economic Theory of Public Enterprise, Berlin, Heidelberg and New York: Springer.

Bös, D. (1986), Public Enterprise Economics, Theory and Application, Amsterdam: Elsevier.

Bohley, P. (2004), Die öffentliche Finanzierung, München and Wien: Oldenbourg.

Boiteux, M. (1951), Le Revenue Distribuable et les Pertes Economique, Econometrica 19, pp. 112-133.

Borodo, A. (2003), Aktuelle Probleme der Kommunalfinanzen Polens angesichts der Reformen von 1990 und 1999, in: Friedrich, P. and J. W. Tkaczyński (Eds.), Wirtschaftsförderung in Polen und Deutschland, Toruń: TNOiK, pp. 39 -56.

Brennan, G. and J. M. Buchanan (1980), The Power to Tax: Analytical Foundations of a Fiscal Constitution, Cambridge: Cambridge University Press. 
Brosio, G. (1985), Fiscal Autonomy of Non-Central Government and the Problem of Public-Spending Growth, in: Forte, F. and A. Peacock (Eds.), Public Expenditure and Government Growth, Oxford: Blackwell, pp. 110-135.

Bundesamt für Statistik (2003), Statistisches Jahrbuch der Schweiz 2003, Zürich: Neue Zürcher Zeitung.

Council of Europe (2000), Effects on the Financial Autonomy of Local and Regional Authorities Resulting from the Limits Set at European Level on National Public Debt, Series of Local and Regional Authorities in Europe No. 71, Strasbourg: Council of Europe Publishing.

Dafflon, B. (1999), Fiscal Federalism in Switzerland: A Survey of Constitutional Issues, Budget Responsibility and Equalisation, in: Fossati, A. and G. Panella, (Ed. 1999), Fiscal Federalism in the European Union, London: Routledge, pp. 255-294.

Dahlby, B. G. (1996), Fiscal Externalities and the Design of Intergovernmental Grants, International Tax and Public Finance 3, pp. 397-412.

Darby, J., A. Mucastelli and G. Roy (2003), Fiscal Decentralisation in Europe: A Review of Recent Experience, in: Mønnesland, J. (Ed.), Regional Public Finances, London: Pion Limited, pp. 13-37.

Davis, A. and R. Lucker (1982), The-Rich-State-Poor-State Problem in a Federal System, National Tax Journal 35, pp. 337-363.

Detig, D. (2004), Die kommunale Anstalt des öffentlichen Rechts als Wirtschaftsförderungsinstitution, Baden-Baden: Nomos.

Eichhorn, P. and P. Friedrich (1976), Verwaltungsökonomie, Baden-Baden: Nomos.

Färber, G. (2000), Theorie und Praxis kommunaler Gebührenkalkulation, Speyerer Forschungsberichte, 214, Hochschule für Verwaltungswissenschaften Speyer, Speyer.

Feng, X. and P. Friedrich (2004), Location Theory of Public Enterprises, Paper presented at the Advanced Studies Summer Institute of the ERSA, 2004, Split.

Friedrich, P. (1969), Investitionskriterien für Gemeindeunternehmen, Tübingen: Mohr.

Friedrich, P. (1971), Die Nutzen-Kosten-Analyse als Entscheidungshilfe für Industrieansiedlungsvorhaben aus der Sicht der isolierten Wohlfahrtsmaximierung, in: NutzenKosten-Analyse bei öffentlichen Investitionen, Institut für Siedlungs- und Wohnungswesen, der Universität Münster, Münster, pp. 163-224.

Friedrich, P. (1978), Ausrichtung der Preisbildung öffentlicher Unternehmen am Grenzkostenpreisprinzip bei differierenden Marktformen, in: Gesellschaft für öffentliche Wirtschaft und Gemeinwirtschaft (Ed.), Kosten und Preise öffentlicher Unternehmen, Berlin: Allgemeine Verlagsgesellschaft, pp. 90-129.

Friedrich, P. (1988), X-Ineffizienz öffentlicher Unternehmen - ein ausschlaggebendes Privatisierungsargument?, in: Brede, H. (Ed.), Privatisierung und die Zukunft der öffentlichen Wirtschaft, Baden-Baden: Nomos, pp. 235-265. 
Friedrich, P. (1992), Der vertikale Wettbewerb im Prinzipal-Agent-Verhältnis: Ein Ansatz zur Weiterentwicklung der Theorie der öffentlichen Unternehmen, in: Friedrich, P., Beiträge zur Theorie öffentlicher Unternehmen, Zeitschrift für öffentliche und gemeinwirtschaftliche Unternehmen, 14 , pp. 178-207.

Friedrich, P. (1998), Gebührensteuerung mittels geeigneter Kostenrechnung - Ein Analyserahmen -, in: Brede, H. (Ed.), Preise und Gebühren in der Entsorgungswirtschaft, Baden-Baden: Nomos, pp. 181-220.

Friedrich, P. (2003), Effects of Taxation on Public Administration, in: Mønnesland, J. (Ed.), Regional Public Finances, London: Pion Limited, pp. 132-151.

Friedrich, P. and X. Feng (2000), The Role of Public Enterprises in Regional Competition, in: Batey, P.W.J. and P. Friedrich (Eds.), Regional Competition, Berlin, Heidelberg and New York: Springer, pp. 186-201.

Friedrich, R., J. Gwiazda and C. W. Nam (2003), Development of Public Finance in Europe, München, CESifo Working Paper 1107.

Fukasaku, K. and L. R. de Mello (Ed. 1999), Fiscal Decentralisation in Emerging Economies, Paris: OECD Development Centre.

Gawel, E. (1995), Die kommunalen Gebühren, Ökonomische, ökologische und rechtliche Ansätze einer gesamtwirtschaftlichen Neuorientierung, Berlin: Duncker \& Humblot.

Gottschalk, W. (1998), Auswirkungen der Rechtsstellung von Entsorgungseinrichtungen auf die Entgeltbemessung (Gebühren, Beiträge, Preise), in: Brede, H. (Ed.), Preise und Gebühren in der Entsorgungswirtschaft, Baden-Baden: Nomos, pp. 79-101.

Grossekettler, H. (1985), Options- und Grenzkostenpreise für Kollektivgüter unterschiedlichster Art und Ordnung, Ein Beitrag zu den Bereitstellungs- und Finanzierungsregeln für öffentliche Leistungen, Finanzarchiv 43, pp. 211- 260.

Hansmeyer, K.-H. and D. Fürst (1968), Die Gebühren, Stuttgart, Berlin, Köln and Mainz: Kohlhammer.

Hutter, R. (1950), La Théorie Economique et la Gestion Commerciale des Chemins de Fer, Le Problème Tarifaire, Revue Générale des Chemins de Fer 69, pp. 318-332.

Jones, P. R. and J. G. Cullis (1994), Bureaucracy and Intergovernmental Grants: A Comment, Kyklos 47, pp. 437-448.

King, D. N. (1984), Fiscal Tiers: The Economics of Multi-Level Government, London: Allen \& Unwin.

Krelle, W. (1976), Preistheorie, II. Teil, Tübingen: Mohr.

Lindemann, S. (1999), Theorie und Empirie kommunalen Wirtschaftsförderungswettbewerbs - eine Konkurrenzanalyse in den neuen Ländern, Baden-Baden: Nomos.

Lösenbeck, H.-D. (1963), Die Preisbildung öffentlicher Unternehmen, Berlin: Duncker \& Humblot. 
Mühlenkamp, H. (1994), Öffentliche Unternehmen, München and Wien: Oldenbourg.

Nam, C. W., R. Parsche and M. Steinherr (2001), The Principles of Parallel Development of Fiscal Capacity between State and Municipalities as Useful Benchmarks for the Determination of the Intergovernmental Grants in Germany, European Planning Studies 9, pp. 525-537.

Nam, C. W. and D. M. Radulescu (2003), A Survey of Municipal Finance in Selected Eastern European Transition Countries, in: Mønnesland, J. (Ed.), Regional Public Finances, London: Pion Limited, pp. 38-52.

Nelson, J. R. (Ed., 1964), Marginal Cost Pricing in Practice, Englewood Cliffs, N.J.: Prentice Hall.

Norregaard, J. (1997), Tax Assignment, in: Ter-Minassian, T. (Ed.), Fiscal Federalism in Theory and Practice, Washington DC: International Monetary Fund, pp. 49-72.

Oates, W. E. (1972), Fiscal Federalism, New York: Harcourt Brace Jovanovich.

Oettle, K. (1998), Gebührenpolitische Wirkungen; Wirkungen auf die Gebührenpolitik, in: Brede, H. (Ed.), Preise und Gebühren in der Entsorgungswirtschaft, BadenBaden: Nomos, pp. 241-263.

Oort, C. J. (1961), Der Marginalismus als Grundlage der Preisbildung in der Verkehrswirtschaft, Rotterdam: Stichting Verkeerswetenschappelijk Centrum.

Pelzman, S. (1971), Pricing in Public and Private enterprises: Electric Utilities in the United States, Journal of Law and Economics 14, pp. 109-147.

Pelzman, S. (1976), Toward a More General Theory of Regulation, Journal of Law and Economics 19, pp. 211-240.

Polish Official Statistics, Regional Data Bank, http://www.stat.gov.pl.

Püttner, G. (1985), Die öffentlichen Unternehmen, Stuttgart, München and Hannover: Boorberg.

Ramsey, F. (1927), A Contribution to the Theory of Taxation, Economic Journal 37, pp. 47-61.

Rees, R. (1976), Public Enterprise Economics, London: Weidenfeld and Nicolson.

Rehm, H. (2004), Kommunale Preispolitik, Zeitschrift für öffentliche und gemeinwirtschaftliche Unternehmen 27, pp. 261-287.

Rogosch, J. K. (1988), Der verfassungsmäßige Rang des gebührenrechtlichen Kostendeckungsprinzips, Kommunal Steuer-Zeitschrift 37, pp. 1-4.

Sacksofsky, U. and J. Wieland (Eds., 2000), Vom Steuerstaat zum Gebührenstaat, Baden-Baden: Nomos.

Seldon, A. (1977), Charge, London: Temple Smith.

Shah, A. (1994a), A Fiscal Need Approach to Equalization Transfers in a Decentralized Federation, The World Bank Policy Research Working Paper Series 1289, Washington DC, The World Bank. 
Shah, A. (1994b), The Reform of Intergovernmental Fiscal Relations in Developing and Emerging Market Economies, The World Bank Policy and Research Series 23, Washington DC: The World Bank.

Shepherd, W.G. (1965), Economic Performance under Public Ownership, New Haven: Yale University Press.

Siekmann, H. (1998), Verfassungsrechtliche Grenzen der Entgeltpolitik in der Entsorgungswirtschaft, in: Brede, H. (Ed.), Preise und Gebühren in der Entsorgungswirtschaft, Baden-Baden: Nomos, pp. 47-78.

Statistisches Bundesamt (2003a), Finanzen und Steuern, Rechnungsergebnisse der kommunalen Haushalte 2001, Fachserie 14, Reihe 3.3, Stuttgart: Poeschel.

Statistisches Bundesamt (2003b), Statistisches Jahrbuch für die Bundesrepublik Deutschland 2003, Stuttgart: Poeschel, and other statistical yearbooks from 1991 on.

Ter-Minassian, T. and J. Craig (1997), Control of Subnational Government Borrowing, in: Ter-Minassian, T. (Ed.), Fiscal Federalism in Theory and Practice, Washington DC: International Monetary Fund, pp. 156-174.

Tettinger, P. (1998), Entgelte in der Entsorgungswirtschaft - Benutzungsgebühren und privatrechtliche Entgelte als normative vorgegebene Grundtypen, in: Brede, H. (Ed.), Preise und Gebühren in der Entsorgungswirtschaft, Baden-Baden: Nomos, pp. 1745.

Thiemeyer, T. (1964), Grenzkostenpreise bei öffentlichen Unternehmen, Köln: Westdeutscher Verlag.

Thiemeyer, T. (1970), Gemeinwirtschaft als Ordnungsprinzip, Berlin: Duncker \& Humblot.

Thiemeyer, T. (1975), Wirtschaftslehre öffentlicher Betriebe, Einbeck: Rowohlt.

Tiebout, C. M. (1956), A Pure Theory of Local Expenditures, Journal of Political Economy 64, pp. 416-424.

Tullock, G. (1969), Federalism: Problem of Scale, Public Choice 6, pp. 19-29.

Turvey, R. (1971), Economic Analysis and Public Enterprises, London: Allen and Unwin.

UK Office of the Deputy Prime Minister (2003), Local Government Financial Statistics, No. 14, London, and from 1993 on.

Wagner, R.E. (Ed. 1991), Charging for Government, User Charges and Earmarked Taxes in Principle and Practice, London: Routledge.

Wienbracke, M. (2004), Bemessungsgrenzen der Verwaltungsgebühr, Berlin: Duncker \& Humblot.

Wirl, F. (1991) Die Theorie öffentlicher Firmen: Rahmenbedingungen für effiziente Versorgungsunternehmen, Baden-Baden: Nomos. 
Ziemes, G. (1992), Politik-ökonomische Betrachtungen öffentlicher Unternehmen, in: Friedrich, P. (Ed.), Beiträge zur Theorie öffentlicher Unternehmen, Zeitschrift für öffentliche und gemeinwirtschaftliche Unternehmen 14, pp. 56-82.

Zimmermann, G. (2003), Die kalkulatorischen Kosten bei Nutzungsentgelten, Gutachten im Auftrag des Bundeskartellamtes, Oldenburg.

Zwehl, W. v. (1991), Benutzungsgebühren, eine zentrale Einnahmenquelle der Kommunen in betriebswirtschaftlicher Sicht, Trier: Wirtschafts- und sozialwissenschaftliche Gesellschaft 


\title{
CESifo Working Paper Series
}

\author{
(for full list see www.cesifo.de)
}

1297 David S. Evans and Michael Salinger, An Empirical Analysis of Bundling and Tying: Over-the-Counter Pain Relief and Cold Medicines, October 2004

1298 Gershon Ben-Shakhar, Gary Bornstein, Astrid Hopfensitz and Frans van Winden, Reciprocity and Emotions: Arousal, Self-Reports, and Expectations, October 2004

1299 B. Zorina Khan and Kenneth L. Sokoloff, Institutions and Technological Innovation During Early Economic Growth: Evidence from the Great Inventors of the United States, 1790 - 1930, October 2004

1300 Piero Gottardi and Roberto Serrano, Market Power and Information Revelation in Dynamic Trading, October 2004

1301 Alan V. Deardorff, Who Makes the Rules of Globalization?, October 2004

1302 Sheilagh Ogilvie, The Use and Abuse of Trust: Social Capital and its Deployment by Early Modern Guilds, October 2004

1303 Mario Jametti and Thomas von Ungern-Sternberg, Disaster Insurance or a Disastrous Insurance - Natural Disaster Insurance in France, October 2004

1304 Pieter A. Gautier and José Luis Moraga-González, Strategic Wage Setting and Coordination Frictions with Multiple Applications, October 2004

1305 Julia Darby, Anton Muscatelli and Graeme Roy, Fiscal Federalism, Fiscal Consolidations and Cuts in Central Government Grants: Evidence from an Event Study, October 2004

1306 Michael Waldman, Antitrust Perspectives for Durable-Goods Markets, October 2004

1307 Josef Honerkamp, Stefan Moog and Bernd Raffelhüschen, Earlier or Later: A General Equilibrium Analysis of Bringing Forward an Already Announced Tax Reform, October 2004

1308 M. Hashem Pesaran, A Pair-Wise Approach to Testing for Output and Growth Convergence, October 2004

1309 John Bishop and Ferran Mane, Educational Reform and Disadvantaged Students: Are They Better Off or Worse Off?, October 2004

1310 Alfredo Schclarek, Consumption and Keynesian Fiscal Policy, October 2004

1311 Wolfram F. Richter, Efficiency Effects of Tax Deductions for Work-Related Expenses, October 2004 
1312 Franco Mariuzzo, Patrick Paul Walsh and Ciara Whelan, EU Merger Control in Differentiated Product Industries, October 2004

1313 Kurt Schmidheiny, Income Segregation and Local Progressive Taxation: Empirical Evidence from Switzerland, October 2004

1314 David S. Evans, Andrei Hagiu and Richard Schmalensee, A Survey of the Economic Role of Software Platforms in Computer-Based Industries, October 2004

1315 Frank Riedel and Elmar Wolfstetter, Immediate Demand Reduction in Simultaneous Ascending Bid Auctions, October 2004

1316 Patricia Crifo and Jean-Louis Rullière, Incentives and Anonymity Principle: Crowding Out Toward Users, October 2004

1317 Attila Ambrus and Rossella Argenziano, Network Markets and Consumers Coordination, October 2004

1318 Margarita Katsimi and Thomas Moutos, Monopoly, Inequality and Redistribution Via the Public Provision of Private Goods, October 2004

1319 Jens Josephson and Karl Wärneryd, Long-Run Selection and the Work Ethic, October 2004

1320 Jan K. Brueckner and Oleg Smirnov, Workings of the Melting Pot: Social Networks and the Evolution of Population Attributes, October 2004

1321 Thomas Fuchs and Ludger Wößmann, Computers and Student Learning: Bivariate and Multivariate Evidence on the Availability and Use of Computers at Home and at School, November 2004

1322 Alberto Bisin, Piero Gottardi and Adriano A. Rampini, Managerial Hedging and Portfolio Monitoring, November 2004

1323 Cecilia García-Peñalosa and Jean-François Wen, Redistribution and Occupational Choice in a Schumpeterian Growth Model, November 2004

1324 William Martin and Robert Rowthorn, Will Stability Last?, November 2004

1325 Jianpei Li and Elmar Wolfstetter, Partnership Dissolution, Complementarity, and Investment Incentives, November 2004

1326 Hans Fehr, Sabine Jokisch and Laurence J. Kotlikoff, Fertility, Mortality, and the Developed World's Demographic Transition, November 2004

1327 Adam Elbourne and Jakob de Haan, Asymmetric Monetary Transmission in EMU: The Robustness of VAR Conclusions and Cecchetti's Legal Family Theory, November 2004

1328 Karel-Jan Alsem, Steven Brakman, Lex Hoogduin and Gerard Kuper, The Impact of Newspapers on Consumer Confidence: Does Spin Bias Exist?, November 2004 
1329 Chiona Balfoussia and Mike Wickens, Macroeconomic Sources of Risk in the Term Structure, November 2004

1330 Ludger Wößmann, The Effect Heterogeneity of Central Exams: Evidence from TIMSS, TIMSS-Repeat and PISA, November 2004

1331 M. Hashem Pesaran, Estimation and Inference in Large Heterogeneous Panels with a Multifactor Error Structure, November 2004

1332 Maarten C. W. Janssen, José Luis Moraga-González and Matthijs R. Wildenbeest, A Note on Costly Sequential Search and Oligopoly Pricing, November 2004

1333 Martin Peitz and Patrick Waelbroeck, An Economist's Guide to Digital Music, November 2004

1334 Biswa N. Bhattacharyay and Prabir De, Promotion of Trade, Investment and Infrastructure Development between China and India: The Case of Southwest China and East and Northeast India, November 2004

1335 Lutz Hendricks, Why Does Educational Attainment Differ Across U.S. States?, November 2004

1336 Jay Pil Choi, Antitrust Analysis of Tying Arrangements, November 2004

1337 Rafael Lalive, Jan C. van Ours and Josef Zweimueller, How Changes in Financial Incentives Affect the Duration of Unemployment, November 2004

1338 Robert Woods, Fiscal Stabilisation and EMU, November 2004

1339 Rainald Borck and Matthias Wrede, Political Economy of Commuting Subsidies, November 2004

1340 Marcel Gérard, Combining Dutch Presumptive Capital Income Tax and US Qualified Intermediaries to Set Forth a New System of International Savings Taxation, November 2004

1341 Bruno S. Frey, Simon Luechinger and Alois Stutzer, Calculating Tragedy: Assessing the Costs of Terrorism, November 2004

1342 Johannes Becker and Clemens Fuest, A Backward Looking Measure of the Effective Marginal Tax Burden on Investment, November 2004

1343 Heikki Kauppi, Erkki Koskela and Rune Stenbacka, Equilibrium Unemployment and Capital Intensity Under Product and Labor Market Imperfections, November 2004

1344 Helge Berger and Till Müller, How Should Large and Small Countries Be Represented in a Currency Union?, November 2004

1345 Bruno Jullien, Two-Sided Markets and Electronic Intermediaries, November 2004 
1346 Wolfgang Eggert and Martin Kolmar, Contests with Size Effects, December 2004

1347 Stefan Napel and Mika Widgrén, The Inter-Institutional Distribution of Power in EU Codecision, December 2004

1348 Yin-Wong Cheung and Ulf G. Erlandsson, Exchange Rates and Markov Switching Dynamics, December 2004

1349 Hartmut Egger and Peter Egger, Outsourcing and Trade in a Spatial World, December 2004

1350 Paul Belleflamme and Pierre M. Picard, Piracy and Competition, December 2004

1351 Jon Strand, Public-Good Valuation and Intrafamily Allocation, December 2004

1352 Michael Berlemann, Marcus Dittrich and Gunther Markwardt, The Value of NonBinding Announcements in Public Goods Experiments: Some Theory and Experimental Evidence, December 2004

1353 Camille Cornand and Frank Heinemann, Optimal Degree of Public Information Dissemination, December 2004

1354 Matteo Governatori and Sylvester Eijffinger, Fiscal and Monetary Interaction: The Role of Asymmetries of the Stability and Growth Pact in EMU, December 2004

1355 Fred Ramb and Alfons J. Weichenrieder, Taxes and the Financial Structure of German Inward FDI, December 2004

1356 José Luis Moraga-González and Jean-Marie Viaene, Dumping in Developing and Transition Economies, December 2004

1357 Peter Friedrich, Anita Kaltschütz and Chang Woon Nam, Significance and Determination of Fees for Municipal Finance, December 2004 